\title{
Evaporation of sulfate aerosols at low relative humidity
}

\author{
Georgios Tsagkogeorgas $^{1}$, Pontus Roldin ${ }^{2,3}$, Jonathan Duplissy ${ }^{2,4}$, Linda Rondo ${ }^{5}$, Jasmin Tröstl ${ }^{6}$, Jay G. Slowik ${ }^{6}$, \\ Sebastian Ehrhart ${ }^{5, \mathrm{a}}$, Alessandro Franchin ${ }^{2}$, Andreas Kürten ${ }^{5}$, Antonio Amorim ${ }^{7}$, Federico Bianchi ${ }^{2}$, \\ Jasper Kirkby $^{5,8}$, Tuukka Petäjä ${ }^{2}$, Urs Baltensperger ${ }^{6}$, Michael Boy ${ }^{2}$, Joachim Curtius $^{5}$, Richard C. Flagan ${ }^{9}$, \\ Markku Kulmala ${ }^{2,4}$, Neil M. Donahue ${ }^{10}$, and Frank Stratmann ${ }^{1}$ \\ ${ }^{1}$ Leibniz Institute for Tropospheric Research, 04318 Leipzig, Germany \\ ${ }^{2}$ Department of Physics, University of Helsinki, P.O. Box 64, 00014 Helsinki, Finland \\ ${ }^{3}$ Division of Nuclear Physics, Lund University, P.O. Box 118, 22100 Lund, Sweden \\ ${ }^{4}$ Helsinki Institute of Physics, University of Helsinki, P.O. Box 64, 00014 Helsinki, Finland \\ ${ }^{5}$ Institute for Atmospheric and Environmental Sciences, Goethe University Frankfurt, 60438 Frankfurt am Main, Germany \\ ${ }^{6}$ Paul Scherrer Institute, 5232 Villigen, Switzerland \\ ${ }^{7}$ Fac. Ciencias \& CENTRA, Universidade de Lisboa, Campo Grande, 1749-016 Lisbon, Portugal \\ ${ }^{8}$ CERN, 1211 Geneva, Switzerland \\ ${ }^{9}$ California Institute of Technology, Pasadena, CA 91125, USA \\ ${ }^{10}$ Center for Atmospheric Particle Studies, Carnegie Mellon University, Pittsburgh, PA 15213, USA \\ ${ }^{a}$ now at: Atmospheric Chemistry Department, Max Planck Institute for Chemistry, 55128 Mainz, Germany
}

Correspondence to: Georgios Tsagkogeorgas (george.tsagkogeorgas@tropos.de)

Received: 23 November 2016 - Discussion started: 16 December 2016

Revised: 10 May 2017 - Accepted: 12 May 2017 - Published: 25 July 2017

\begin{abstract}
Evaporation of sulfuric acid from particles can be important in the atmospheres of Earth and Venus. However, the equilibrium constant for the dissociation of $\mathrm{H}_{2} \mathrm{SO}_{4}$ to bisulfate ions, which is the one of the fundamental parameters controlling the evaporation of sulfur particles, is not well constrained. In this study we explore the volatility of sulfate particles at very low relative humidity. We measured the evaporation of sulfur particles versus temperature and relative humidity in the CLOUD chamber at CERN. We modelled the observed sulfur particle shrinkage with the ADCHAM model. Based on our model results, we conclude that the sulfur particle shrinkage is mainly governed by $\mathrm{H}_{2} \mathrm{SO}_{4}$ and potentially to some extent by $\mathrm{SO}_{3}$ evaporation. We found that the equilibrium constants for the dissociation of $\mathrm{H}_{2} \mathrm{SO}_{4}$ to $\mathrm{HSO}_{4}^{-}\left(\mathrm{K}_{\mathrm{H}_{2} \mathrm{SO}_{4}}\right)$ and the dehydration of $\mathrm{H}_{2} \mathrm{SO}_{4}$ to $\mathrm{SO}_{3}\left({ }^{x} K_{\mathrm{SO}_{3}}\right)$ are $K_{\mathrm{H}_{2} \mathrm{SO}_{4}}=2-4 \times 10^{9} \mathrm{~mol} \mathrm{~kg}^{-1}$ and ${ }^{x} K_{\mathrm{SO}_{3}} \geq 1.4 \times 10^{10}$ at $288.8 \pm 5 \mathrm{~K}$.
\end{abstract}

\section{Introduction}

Suspended particulate matter in the atmosphere plays a key role in Earth's climate. Atmospheric aerosol particles affect the amount of solar radiation absorbed by the Earth system. This is accomplished either when atmospheric aerosol particles directly absorb or scatter incoming solar energy (causing warming or cooling) or when particles act as cloud condensation or ice nuclei (leading to an increase in cloud albedo, which causes cooling). A substantial fraction of particle number and mass across a wide range of environmental conditions arises from sulfur emissions (Clarke et al., 1998; Turco et al., 1982).

Sulfur in Earth's atmosphere in turn originates from natural phenomena like volcanic eruptions and biota decomposition. Violent volcanic eruptions can loft sulfur dioxide $\left(\mathrm{SO}_{2}\right)$ to the stratosphere, which can then form sulfur aerosol particles. Those sulfur aerosols can remain suspended in the stratosphere for $\sim 1-2$ years before falling into the troposphere (Wilson et al., 1993; Deshler, 2008). The three main natural agents for sulfate aerosol formation in troposphere are dimethyl sulfide (DMS), which arises from marine phyto- 
plankton decomposition (Charlson et al., 1987; Kiene, 1999; Simó and Pedrós-Alió, 1999), $\mathrm{SO}_{2}$, which occurs naturally as a decay product of plant and animal matter (Grädel and Crutzen, 1994; Hübert, 1999; Capaldo et al., 1999), and carbonyl sulfide (OCS), which is emitted from anaerobic biological activity and provides the main non-volcanic flux of sulfur into the stratosphere (Galloway and Rodhe, 1991; Rhode, 1999).

The atmospheric sulfate burden is substantially perturbed by sulfur emissions associated with anthropogenic activities. The largest anthropogenic source of sulfur is fossil-fuel combustion; coal is the predominant source, but also heavy fuel oil is important (Öm et al., 1996; Smith et al., 2001). Fossilfuel combustion constitutes $\sim$ two-thirds of the total global sulfur flux to the atmosphere (Rhode, 1999; Wen and Carignan, 2007) and dominates emissions in most populated regions. Other anthropogenic factors also affect the sulfuric acid $\left(\mathrm{H}_{2} \mathrm{SO}_{4}\right)$ budget, notably sulfur aerosol formation in aircraft plumes (Fahey et al., 1995; Curtius et al., 1998), and extensive sulfur use in industry with a direct environmental impact on local scale. However, on a regional to global scale the acidification of fresh water and forest ecosystems is mainly caused by wet and dry deposition of $\mathrm{SO}_{2}$ and sulfate particles (Simpson et al., 2006).

Sulfur is also a crucial constituent in Venus' atmosphere, an environment with very low relative humidity (RH) (Moroz et al., 1979; Hoffman et al., 1980), forming the main cloud layer in the form of sulfuric acid droplets (Donahue et al., 1982), which are maintained in an intricate photochemical cycle (photooxidation of OCS; Prinn, 1973). Sulfuric acid's reaction paths remain a subject of investigation (Zhang et al., 2010), which makes the study of the sulfur cycle (including the sulfur species $\mathrm{SO}, \mathrm{SO}_{2}, \mathrm{SO}_{3}, \mathrm{H}_{2} \mathrm{SO}_{4}$ ) an important endeavour for understanding both the chemistry and climate of Venus (Mills et al., 2007; Hashimoto and Abe, 2000).

$\mathrm{H}_{2} \mathrm{SO}_{4}$ serves as an effective nucleating species and, thus, strongly influences atmospheric new-particle formation (Laaksonen and Kulmala, 1991; Weber et al., 1999; Kulmala et al., 2000; Yu and Turco, 2001; Fiedler et al., 2005; Kuang et al., 2008). The nucleation rate, which is the formation rate $\left(\mathrm{cm}^{-3} \mathrm{~s}^{-1}\right)$ of new particles at the critical size, strongly depends upon the saturation ratio of $\mathrm{H}_{2} \mathrm{SO}_{4}$. Uncertainty in this ratio results in an uncertainty of several orders of magnitude in the calculated nucleation rate (Roedel, 1979). To model the excess $\mathrm{H}_{2} \mathrm{SO}_{4}$ responsible for the gas-to-particle conversion it is necessary to know the vapour pressure of $\mathrm{H}_{2} \mathrm{SO}_{4}$ over sulfuric acid and/or neutralised solutions.

The sulfuric acid vapour pressure appears through the freeenergy term in the exponent of the new-particle formation rate (Volmer and Weber, 1926; Stauffer, 1976). Quantitative theoretical predictions of nucleation rates are highly uncertain because the pure $\mathrm{H}_{2} \mathrm{SO}_{4}$ equilibrium vapour pressure is not well known (Gmitro and Vermeulen, 1964; Doyle, 1961; Kiang and Stauffer, 1973). However, accurate calculations of the $\mathrm{H}_{2} \mathrm{SO}_{4}$ vapour pressure require accurate equilibrium rate constant values to constrain the reactions of formation and dissociation of $\mathrm{H}_{2} \mathrm{SO}_{4}$ in aqueous solutions.

While $\mathrm{H}_{2} \mathrm{SO}_{4}$ is often presumed to be practically nonvolatile, this is not always the case. There are several circumstances on Earth and Venus where the vapour pressure of $\mathrm{H}_{2} \mathrm{SO}_{4}$ matters: specifically, at very low $\mathrm{RH}$, high temperature $(T)$, when there is a deficit of stabilising bases, and when particles are very small. A very important region of Earth's environment is the upper stratosphere, where these conditions prevail (Vaida et al., 2003). Under these conditions $\mathrm{H}_{2} \mathrm{SO}_{4}$ can evaporate from particles. This can either inhibit growth of nanoparticles or lead them to shrink.

Furthermore, molecular $\mathrm{H}_{2} \mathrm{SO}_{4}$ is never the dominant constituent in sulfuric acid solutions. It will completely dehydrate to sulfur trioxide $\left(\mathrm{SO}_{3}\right.$, which is extremely volatile) in a truly dry system and yet almost entirely dissociate into bisulfate ion $\left(\mathrm{HSO}_{4}^{-}\right)$and hydronium cation $\left(\mathrm{H}_{3} \mathrm{O}^{+}\right)$in the presence of even trace water $\left(\mathrm{H}_{2} \mathrm{O}\right)$ (Clegg and Brimblecombe, 1995). This is why $\mathrm{H}_{2} \mathrm{SO}_{4}$ is such a powerful desiccant. Also, bases such as ammonia $\left(\mathrm{NH}_{3}\right)$ will enhance chemical stabilisation and form sulfate salts. The thermodynamics of the $\mathrm{H}_{2} \mathrm{SO}_{4}-\mathrm{H}_{2} \mathrm{O}$ system at low $\mathrm{RH}$ are uncertain, so we seek to improve our understanding of this part of the phase diagram. To accomplish this, we measured the shrinkage of nearly pure $\mathrm{H}_{2} \mathrm{SO}_{4}$ particles in the CLOUD chamber at CERN at very low RH and then simulated these experiments with an aerosol dynamics model coupled with a thermodynamics model to constrain the equilibrium constants, for the dissociation $K_{\mathrm{H}_{2} \mathrm{SO}_{4}}$ and the dehydration ${ }^{x} \mathrm{~K}_{\mathrm{SO}_{3}}$, of $\mathrm{H}_{2} \mathrm{SO}_{4}$ coupling $\mathrm{HSO}_{4}^{-}, \mathrm{H}_{2} \mathrm{SO}_{4}$, and $\mathrm{SO}_{3}$. These new values can be used in models that simulate the evolution of sulfate aerosol particles in the atmospheres of Venus and Earth.

\section{Aqueous-phase sulfuric acid reactions}

$\mathrm{H}_{2} \mathrm{SO}_{4}$ dissociation and potential dehydration to $\mathrm{SO}_{3}$ are the principal subjects of this study. In aqueous solutions $\mathrm{H}_{2} \mathrm{SO}_{4}$ can dissociate in two steps.

$$
\begin{aligned}
& \mathrm{H}_{2} \mathrm{SO}_{4}(\mathrm{aq}) \stackrel{K_{\mathrm{H}_{2} \mathrm{SO}_{4}}}{\longleftrightarrow} \mathrm{HSO}_{4}(\mathrm{aq})^{-}+\mathrm{H}^{+} \\
& \mathrm{HSO}_{4}(\mathrm{aq})^{-} \stackrel{K_{\mathrm{HSO}_{4}^{-}}}{\longleftrightarrow} \mathrm{SO}_{4}(\mathrm{aq})^{2-}+\mathrm{H}^{+}
\end{aligned}
$$

$\mathrm{H}_{2} \mathrm{SO}_{4}$ partially dissociates to form $\mathrm{HSO}_{4}^{-}$via Reaction (R1). $K_{\mathrm{H}_{2} \mathrm{SO}_{4}}$ represents the equilibrium constant for Reaction (R1). $\mathrm{HSO}_{4}^{-}$can then undergo a second dissociation Reaction ( $\mathrm{R} 2)$ to form a sulfate ion $\left(\mathrm{SO}_{4}^{2-}\right)$. In the above reactions, sulfur's oxidation number is $6(\mathrm{~S}(\mathrm{VI}))$.

For dilute aqueous solutions, Reaction (R1) is considered to be complete. However, when the mole fraction of $\mathrm{S}(\mathrm{VI})$ exceeds $\sim 0.5, \mathrm{H}_{2} \mathrm{SO}_{4}$ can be detected in the solution (Walrafen et al., 2000; Margarella et al., 2013). When $\mathrm{H}_{2} \mathrm{SO}_{4}$ is present in the solution, dehydration of $\mathrm{H}_{2} \mathrm{SO}_{4}$ to form $\mathrm{SO}_{3}$ (Reaction R3) can also be important (Wang et al., 2006; Que 
et al., 2011). ${ }^{x} K_{\mathrm{SO}_{3}}$ represents the equilibrium constant for Reaction (R3) on a mole fraction basis.

$\mathrm{SO}_{3}(\mathrm{aq})+\mathrm{H}_{2} \mathrm{O} \stackrel{x}{\longleftrightarrow} \mathrm{KSO}_{3} \mathrm{H}_{2} \mathrm{SO}_{4}(\mathrm{aq})$

$\mathrm{NH}_{3}$, which mainly originates from anthropogenic agriculture emissions, is the most abundant base in atmospheric secondary aerosol particles. $\mathrm{NH}_{3}$ neutralises sulfuric acid particles by reacting with $\mathrm{H}^{+}$and forming an ammonium ion $\left(\mathrm{NH}_{4}^{+}\right.$) (Reaction R4).

$\mathrm{NH}_{3}(\mathrm{aq})+\mathrm{H}^{+} \stackrel{K_{\mathrm{NH}_{3}}}{\longleftrightarrow} \mathrm{NH}_{4}{ }^{+}$

Even in the cleanest environments, such as the stratosphere, $\mathrm{NH}_{3}$ is present at low concentrations and $\mathrm{NH}_{3(\mathrm{~g})}$ will be dissolved in the acidic sulfate particles.

\section{Methods}

In the CLOUD (Cosmics Leaving OUtdoor Droplets; Kirkby et al., 2011) chamber at CERN, we measured the $\mathrm{H}_{2} \mathrm{SO}_{4}$ aerosol particle evaporation under precisely controlled temperature and relative humidity. We designed experiments to accomplish a gradual decrease in RH (from 11.0 to $0.3 \%$ ) under atmospherically relevant conditions. To understand the processes governing the measured particle evaporation, we modelled the experiments with the Aerosol Dynamics, gasand particle-phase chemistry model for laboratory CHAMber studies (ADCHAM; Roldin et al., 2014).

\subsection{Experimental setup}

Details of the CLOUD chamber, the main element of the experimental setup can be found in Kirkby et al. (2011) and Duplissy et al. (2016). For the experiments described here, we formed and grew sulfuric acid particles in the chamber by oxidising $\mathrm{SO}_{2}$ with $\mathrm{OH}$ radicals that were generated by photolysing $\mathrm{O}_{3}$ and allowing the resulting $\mathrm{O}\left({ }^{1} \mathrm{D}\right)$ to react with water vapour. During these experiments we fed the aerosol population to an array of instruments for characterisation of both physical and chemical properties.

We utilised the following instruments to measure gasphase concentrations: a $\mathrm{SO}_{2}$ monitor (enhanced trace level $\mathrm{SO}_{2} 15$ analyser, model 43i-TLE, Thermo Scientific, USA), an $\mathrm{O}_{3}$ monitor (TEI 49C, Thermo Environmental Instruments, USA) and a chemical ionisation mass spectrometer (CIMS) to measure the gas-phase $\mathrm{H}_{2} \mathrm{SO}_{4}$ concentration $\left(\left[\mathrm{H}_{2} \mathrm{SO}_{4(\mathrm{~g})}\right]\right.$ between $\sim 5 \times 10^{5}$ and $\sim 3 \times 10^{9} \mathrm{~cm}^{-3}$; Kürten et al., 2011, 2012). The CIMS data provided the total gaseous sulfuric acid concentration, $\left[\mathrm{H}_{2} \mathrm{SO}_{4(\mathrm{~g})}\right]$, without constraining the hydration state of the evaporating molecules (e.g. $\mathrm{H}_{2} \mathrm{SO}_{4}$ associated with one, two, or three $\mathrm{H}_{2} \mathrm{O}$ molecules).

We measured the evolution of the aerosol number size distribution with a scanning mobility particle sizer (SMPS;
Wang and Flagan, 1990), which recorded the dry particle mobility diameter in the size range from about 10 to $220 \mathrm{~nm}$. We operated the SMPS system with a recirculating dried sheath flow ( $\mathrm{RH}<14 \%$ controlled by a silicon dryer) with a sheath to aerosol sample flow ratio of $3: 0.3 \mathrm{~L}$. We maintained the differential mobility analyser (DMA) and recirculating system at $278-288 \mathrm{~K}$ by means of a temperature control rack, while we operated the condensation particle counter (CPC) at room temperature. We corrected the SMPS measurements for charging probability, including the possibility of multiple charges, diffusion losses, and CPC detection efficiency.

We measured aerosol particle chemical composition with an Aerodyne aerosol mass spectrometer (AMS) quantifying sulfate, nitrate, ammonium and organics for particles between 50 and $1000 \mathrm{~nm}$ aerodynamic diameter (Jimenez et al., 2003; Drewnick et al., 2006; Canagaratna et al., 2007). The AMS provided the mass concentration measurements $\left(\mu \mathrm{g} \mathrm{m}^{-3}\right)$ calculated from the ion signals by using measured air sample flow rate, nitrate ionisation efficiency (IE) and relative IE of the other species.

\subsection{The experimental procedure}

To study aerosol particle evaporation, the formation of sulfuric acid particles preceded. At the lowest $\mathrm{H}_{2} \mathrm{O}$ levels $(\mathrm{RH}<11 \%)$ and in the presence of $\mathrm{O}_{3}$, controlled $\mathrm{UV}$ photo-excitation reactions initiated the oxidation of $\mathrm{SO}_{2}$ to $\mathrm{H}_{2} \mathrm{SO}_{4}$. Sulfuric acid particles nucleated and grew to a size of $\sim 220 \mathrm{~nm}$ by condensation of $\mathrm{H}_{2} \mathrm{SO}_{4(\mathrm{~g})}$ at a quasiconstant gas-phase concentration $\left(\sim 1 \times 10^{9} \mathrm{~cm}^{-3}\right.$ with an uncertainty of $>20 \%$ ). The $\mathrm{H}_{2} \mathrm{SO}_{4}$ formation and particle growth ended when we closed the shutters in the front of the UV light source. Afterwards, we induced particle shrinkage by decreasing the RH. We decreased the RH in two separate ways; either by minimising the influx of water vapour to the chamber, or by increasing the temperature. This separation in experimental procedures gave the ability to achieve and control extremely low RH values (Table 1).

After the end of the particle formation period and during the initial steps of evaporation, before the RH started to decrease, the aerosol size distribution remained nearly constant. Subsequently, the RH decreased gradually initiating the particle evaporation. When the $\mathrm{RH}$ reached a certain low value ( $\mathrm{RH} \leq 1.5 \%$ for $T=288.8 \mathrm{~K}$ ) the particles shrank rapidly, as revealed by the SMPS measurements, and the $\left[\mathrm{H}_{2} \mathrm{SO}_{4(\mathrm{~g})}\right]$ increased until it reached a peak value (see Supplement, Fig. S1). The $\left[\mathrm{H}_{2} \mathrm{SO}_{4(\mathrm{~g})}\right]_{\text {peak }}$ was significantly higher than the background concentration before the onset of evaporation (Table 1). After reaching a maximum in gas-phase concentration, the sulfuric acid decreased again, though the size distribution remained stable (e.g. $\sim 50( \pm 10) \mathrm{nm}$ for experiments 1 and 2; see Sect. 4.3) depending on the RH and $T$ conditions. This behaviour revealed that the remaining aerosol could not be pure sulfuric acid but rather consisted of a more stable chemical mixture that inhibited further evaporation. 
Table 1. Summary of the experimental conditions: temperature $(T)$, relative humidity $(\mathrm{RH})$, and gaseous sulfuric acid concentration $\left(\left[\mathrm{H}_{2} \mathrm{SO}_{4(\mathrm{~g})}\right]\right)$ which is also given as saturation vapour pressure $\left(p_{\mathrm{sat}, \mathrm{H}_{2} \mathrm{SO}_{4}}\right)$ for each experiment.

\begin{tabular}{|c|c|c|c|c|c|c|c|}
\hline Run No & $\begin{array}{l}\text { CLOUD } \\
\text { Run No }\end{array}$ & $\begin{array}{c}T \\
(\mathrm{~K})\end{array}$ & $\begin{array}{l}\mathrm{RH} \\
(\%)\end{array}$ & $\begin{array}{r}{\left[\mathrm{H}_{2} \mathrm{SO}_{4(\mathrm{~g})}\right], \text { peak }} \\
\left(\# \mathrm{~cm}^{-3}\right)\end{array}$ & $\begin{array}{r}{\left[\mathrm{H}_{2} \mathrm{SO}_{4(\mathrm{~g})}\right] \text {, background }} \\
\left(\# \mathrm{~cm}^{-3}\right)\end{array}$ & $\begin{array}{l}p_{\text {sat, } \mathrm{H}_{2} \mathrm{SO}_{4},} \\
\text { peak }(\mathrm{Pa})\end{array}$ & $\begin{array}{l}p_{\text {sat }, \mathrm{H}_{2} \mathrm{SO}_{4}} \\
\text { background }(\mathrm{Pa})\end{array}$ \\
\hline 1 & & 288.8 & $10.1-0.5$ & $6.0 \times 10^{7}$ & $1.2 \times 10^{7}$ & $2.3 \times 10^{-7}$ & $5.0 \times 10^{-8}$ \\
\hline 2 & 914.06 & 288.8 & 3.5 & $2.3 \times 10^{8}$ & $1.0 \times 10^{8}$ & $9.0 \times 10^{-7}$ & $4.2 \times 10^{-7}$ \\
\hline 3 & 919.02-04 & $268.0-293.0$ & $1.4-0.3$ & $1.8 \times 10^{9}$ & $2.0 \times 10^{8}$ & $6.3 \times 10^{-6}$ & $2.7 \times 10^{-7}$ \\
\hline
\end{tabular}

Similarly, the AMS recorded the evaporation of particles (see Supplement, Fig. S1). The AMS measurements showed that the particles were composed almost exclusively of sulfuric acid (but not pure $\mathrm{H}_{2} \mathrm{SO}_{4}$ ). Based on AMS data, calculations of the kappa value ( $\kappa$; Petters and Kreidenweis, 2007), which is defined as a parameter that describes the aerosols water uptake and cloud condensation nucleus activity (CCN activity), of the mixed particles as a function of time during particle evaporation (see Supplement, Fig. S2) yield a value close to the $\kappa$ for pure sulfuric acid particles (Sullivan et al., 2010). A $\kappa$ value is indicative of the solubility of aerosol particles, with $\kappa=0$ referring to an insoluble particle and $\kappa=0.7$ to pure sulfuric acid particles. $\kappa$ is computed by the approximate equation, Eq. (1)

$\kappa=\frac{4 \cdot A^{3}}{27 \cdot D_{\mathrm{d}}^{3} \cdot \ln ^{2} S_{\mathrm{c}}}$

when the critical diameter $D_{\mathrm{d}}$ and critical saturation $S_{\mathrm{c}}$ (or supersaturation, $s_{\mathrm{c}}$, when referring to $\mathrm{CCN}$ activity) are known. The term $A$ can be calculated from the water properties.

\subsection{The model framework}

In the present work we use ADCHAM (Roldin et al., 2014, 2015) to study the evolution of the particle number size distribution and particle chemical composition. Instead of simulating the new-particle formation in the CLOUD chamber, we use the measured particle number size distribution before the UV lights are turned off as well as time sequences of RH, $T$ and $\left[\mathrm{H}_{2} \mathrm{SO}_{4(\mathrm{~g})}\right]$ as inputs to the model (Fig. 1). In order to capture the evolution of the particle number size distribution we consider Brownian coagulation, particle wall deposition, condensation and evaporation of $\mathrm{H}_{2} \mathrm{SO}_{4}, \mathrm{SO}_{3}$ and $\mathrm{H}_{2} \mathrm{O}$ from the particles.

\subsubsection{The activity coefficients}

Within an aqueous electrolyte solution, such as the $\mathrm{H}_{2} \mathrm{SO}_{4}-$ $\mathrm{SO}_{3}-\mathrm{H}_{2} \mathrm{O}$ system, cations, anions and molecular species all disrupt ideality. Here, we consider interactions between ions $\left(\mathrm{HSO}_{4}^{-}, \mathrm{SO}_{4}^{2-}, \mathrm{NH}_{4}^{+}, \mathrm{H}^{+}\right)$and molecules $\left(\mathrm{H}_{2} \mathrm{SO}_{4}, \mathrm{SO}_{3}\right.$, $\mathrm{H}_{2} \mathrm{O}$ ) in the particle-phase chemistry model. To calculate the molality-based activity coefficients for the inorganic ions $\left(\gamma_{\mathrm{i}}\right)$ and the mole-fraction-based activity coefficient for water $\left(f_{\mathrm{H}_{2} \mathrm{O}}\right)$ we apply the Aerosol Inorganic Organic Mixtures Functional groups Activity Coefficients (AIOMFAC) model (validated at room temperatures; Zuend et al., 2008, 2011). The reference state for ions and water in the model is an infinitely dilute aqueous solution $\left(\gamma_{\mathrm{i}}\left(\chi_{\mathrm{H}_{2} \mathrm{O}} \rightarrow 1\right)=1\right.$ and $f_{\mathrm{H}_{2} \mathrm{O}}\left(\chi_{\mathrm{H}_{2} \mathrm{O}} \rightarrow 1\right)=1$.

For relatively dilute $\mathrm{H}_{2} \mathrm{SO}_{4(\mathrm{aq})}$ solutions (low solute concentration), typical for most atmospheric conditions, it is reasonable to assume that the dissociation of $\mathrm{H}_{2} \mathrm{SO}_{4}$ to $\mathrm{HSO}_{4}^{-}$ (Reaction R1) is complete (Clegg et al., 1998; Zuend et al., 2008). However, in this work we demonstrate that this assumption fails at low RH and also for small particles with a large Kelvin term. Furthermore, at a very low water activity $\left(a_{\mathrm{w}}\right)$ (less than $\left.\sim 0.01\right)$ a non-negligible fraction of the $\mathrm{H}_{2} \mathrm{SO}_{4}$ could potentially decompose to $\mathrm{SO}_{3}$ (Reaction R3); if this is the case, the thermodynamic model need to consider not only Reaction (R1) but (R3) as well (Fig. 1).

Since AIOMFAC does not consider inorganic nonelectrolyte compounds like $\mathrm{H}_{2} \mathrm{SO}_{4}$ and $\mathrm{SO}_{3}$ we implement additionally to this the symmetric electrolyte-NonRandom Two-Liquid (eNRTL) activity coefficient model (Bollas et al., 2008; Song and Chen, 2009) which is optimised for the $\mathrm{H}_{2} \mathrm{SO}_{4}-\mathrm{H}_{2} \mathrm{O}-\mathrm{SO}_{3}$ systems by Que et al. (2011). In this work we use the regressed eNRTL binary interaction parameters from Que et al. (2011). Following the convention of the eNRTL model (Chen et al., 1982), we set the unknown binary parameters for $\mathrm{NH}_{4}^{+}$-molecule, molecule- $\mathrm{NH}_{4}^{+}$and $\mathrm{NH}_{4}^{+}-$ ions to $-4,8$ and 0 , respectively.

The reference state of the molecular species in eNRTL is defined as the pure liquid. eNRTL provides mole-fractionbased activity coefficients for $\mathrm{H}_{2} \mathrm{SO}_{4}$ and $\mathrm{SO}_{3}, f_{\mathrm{H}_{2} \mathrm{SO}_{4}}$ and

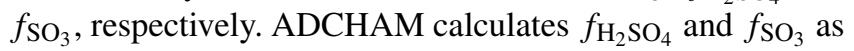
a function of $a_{\mathrm{w}}$ and $\mathrm{N}: \mathrm{S}, \chi_{\mathrm{N}(-\mathrm{III})}: \chi_{\mathrm{S}(\mathrm{VI})}$ (Fig. S3). The modelled $f_{\mathrm{H}_{2} \mathrm{SO}_{4}}$ and $f_{\mathrm{SO}_{3}}$ approach unity not only at the standard state of the pure liquids $\left(f_{\mathrm{H}_{2} \mathrm{SO}_{4}}\left(\chi_{\mathrm{H}_{2} \mathrm{SO}_{4}} \rightarrow 1\right)=1\right.$ and $\left.f_{\mathrm{SO}_{3}}\left(\chi_{\mathrm{SO}_{3}} \rightarrow 1\right)=1\right)$, but also for the infinitely dilute aqueous solution $\left(f_{\mathrm{H}_{2} \mathrm{SO}_{4}}\left(\chi_{\mathrm{H}_{2} \mathrm{O}} \rightarrow 1\right)=1\right.$ and $f_{\mathrm{SO}_{3}}\left(\chi_{\mathrm{H}_{2} \mathrm{O}} \rightarrow\right.$ $1)=1$ ). This is because the eNRTL binary $\mathrm{H}_{2} \mathrm{O}-\mathrm{H}_{2} \mathrm{SO}_{4}$ and $\mathrm{H}_{2} \mathrm{O}-\mathrm{SO}_{3}$ interaction parameters are zero in the model. For all conditions between these limiting states, the shortrange ion $\left(\mathrm{HSO}_{4}^{-}, \mathrm{SO}_{4}^{2-}, \mathrm{NH}_{4}^{+}, \mathrm{H}^{+}\right)$-molecule $\left(\mathrm{H}_{2} \mathrm{SO}_{4}\right.$, $\mathrm{SO}_{3}$ ) interactions, and Pitzer-Debye-Hückel long-range ion-molecule interactions influence the modelled $f_{\mathrm{H}_{2} \mathrm{SO}_{4}}$ and 


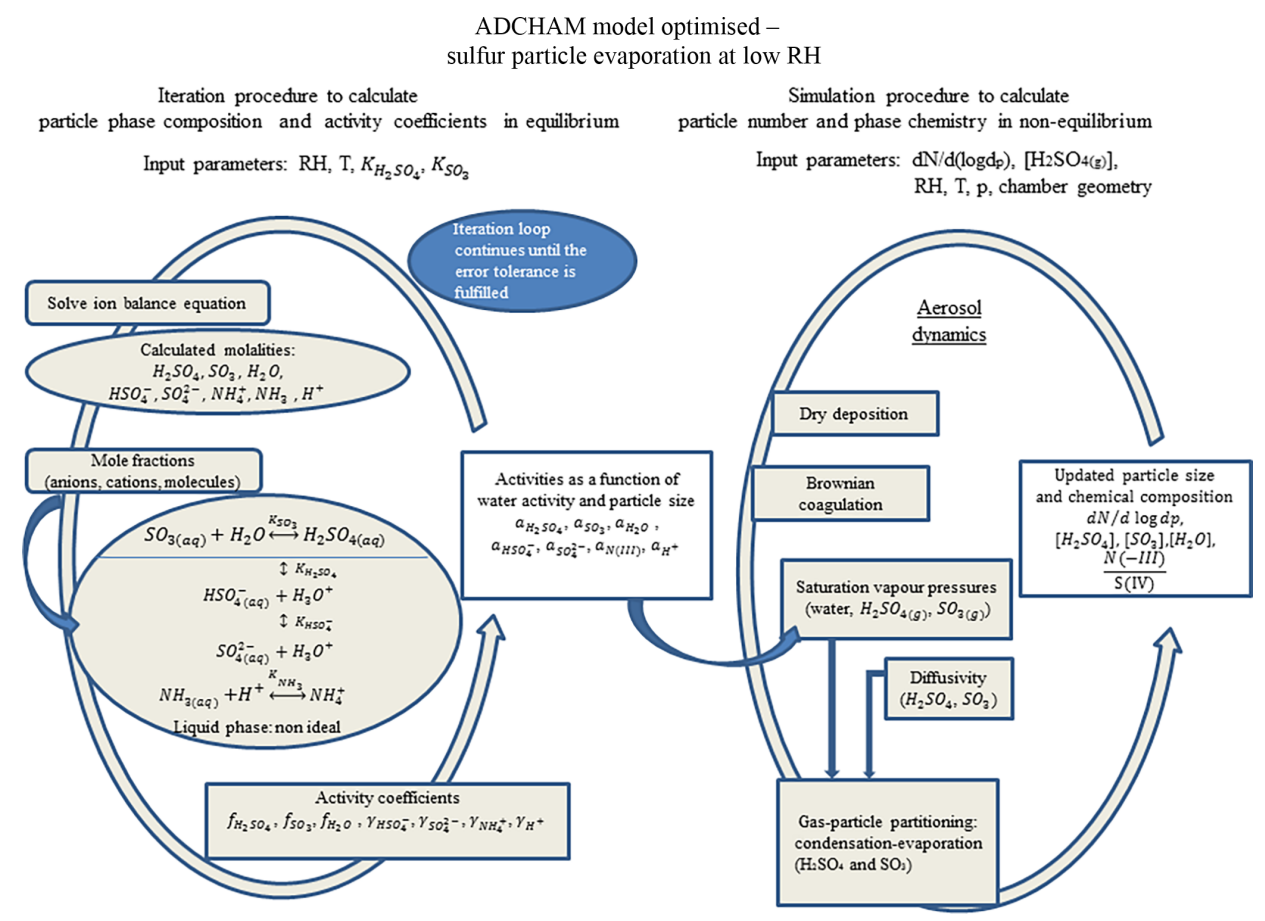

Figure 1. Schematic of the ADCHAM model optimised for the sulfur particle evaporation at low RH.

$f_{\mathrm{SO}_{3}}$. At $T=288.8 \mathrm{~K}, f_{\mathrm{H}_{2} \mathrm{SO}_{4}}$ reaches the highest values $(\sim 2.29)$ when $a_{\mathrm{w}} \approx 0.25$ and $f_{\mathrm{SO}_{3}}$ reaches the highest values $(\sim 1.95)$ when $a_{\mathrm{w}} \approx 0.35$ (Fig. S3). We also assume that the activity coefficient of $\mathrm{NH}_{3}$ is unity for the model simulations. However, sensitivity tests performed for $\gamma \mathrm{NH}_{3}=0.1$ and $\gamma_{\mathrm{NH}_{3}}=10$ reveal that, for the acidic particles $(\mathrm{N}: \mathrm{S}<1)$, our model results are completely insensitive of the absolute value of $\gamma_{\mathrm{NH}_{3}}$.

\subsubsection{The particle-phase composition}

If ammonium cation $\left(\mathrm{NH}_{4}^{+}\right)$is present in the sulfuric acid particles, then solid ammonium bisulfate $\left(\mathrm{NH}_{4} \mathrm{HSO}_{4}(\mathrm{~s})\right)$ may form when the $\mathrm{S}(\mathrm{VI})$ and $\mathrm{H}_{2} \mathrm{O}$ start to evaporate from the particles. However, the particles may also stay as highly supersaturated droplets with respect to the crystalline phase (Zuend et al., 2011). The particle number size distribution measurements in our experiments do not indicate a sudden drop in particle size during evaporation. This is expected when the particles crystalise and all particle water is suddenly removed. Thus, in the present work we do not consider formation of any solid salts. We further neglect the influence of any mass-transfer limitations in the particle phase, and assume that the particle ion-molecule equilibrium composition (Reactions R1-R3) and water content can be modelled as equilibrium processes (because they are established rapidly compared to the composition change induced by the evaporation of $\mathrm{H}_{2} \mathrm{SO}_{4}$ and $\mathrm{SO}_{3}$ ). We use the thermodynamic model to update the particle equilibrium water content, mole fractions and activity coefficients of all species. Then the model considers the gas-particle partitioning of $\mathrm{H}_{2} \mathrm{SO}_{4}$ and $\mathrm{SO}_{3}$ with a condensation algorithm in the aerosol dynamics model (Sect. 3.3.5). The time step set in the model is $1 \mathrm{~s}$.

The thermodynamic model uses an iterative approach to calculate the particle equilibrium mole fractions of $\mathrm{H}_{2} \mathrm{O}$, $\mathrm{H}_{2} \mathrm{SO}_{4}, \mathrm{SO}_{3}, \mathrm{HSO}_{4}^{-}, \mathrm{SO}_{4}^{2-}, \mathrm{NH}_{3}, \mathrm{NH}_{4}^{+}$and $\mathrm{H}^{+}$, based on the current time step, known $\mathrm{RH}$, and absolute number of moles of $\mathrm{S}(\mathrm{VI})$ and $\mathrm{N}(-\mathrm{III})$ for each particle size bin. The modelled particle-phase mole fraction of $\mathrm{N}(-\mathrm{III})$ during the evaporation experiments is always substantially lower than that of $\mathrm{S}(\mathrm{VI})(\mathrm{N}: \mathrm{S}<0.7)$. For these particles the saturation vapour pressure of $\mathrm{NH}_{3}$ is always less than $10^{-10} \mathrm{~Pa}$, within the experimental water activity range $0-0.11$ and $\gamma \mathrm{NH}_{3} \geq 0.1$. Thus, it is reasonable to assume that during the experiments $\mathrm{NH}_{3}$ does not evaporate from the particles.

Based on the particle diameters from the previous time step (which depend on the particle water content), the thermodynamic model starts by calculating $a_{\mathrm{w}}$ for each particle size, considering the Kelvin effect. Given $a_{\mathrm{w}}$, the model estimates the particle water mole fraction. Then the model calculates the $\mathrm{H}^{+}$molality in the aqueous phase via a fourthorder polynomial, derived from the ion balance equation, Eq. (2), in combination with the thermodynamic equilibrium constant equations, Eqs. (3)-(6), and the S(VI) and N(-III) mole balance equations, Eqs. (7) and (8), respectively. The maximum positive real root of this polynomial gives the $\mathrm{H}^{+}$ 
concentration, $\left[\mathrm{H}^{+}\right]$.

$$
\begin{aligned}
& {\left[\mathrm{H}^{+}\right]+\left[\mathrm{NH}_{4}^{+}\right]=\left[\mathrm{HSO}_{4}^{-}\right]+2\left[\mathrm{SO}_{4}^{2-}\right]} \\
& K_{\mathrm{H}_{2} \mathrm{SO}_{4}}=\frac{\left[\mathrm{HSO}_{4}^{-}\right] \cdot \gamma_{\mathrm{HSO}_{4}^{-}} \cdot\left[\mathrm{H}^{+}\right] \cdot \gamma_{\mathrm{H}^{+}}}{\left[\mathrm{H}_{2} \mathrm{SO}_{4}\right] \cdot \gamma_{\mathrm{H}_{2} \mathrm{SO}_{4}}} \\
& K_{\mathrm{HSO}_{4}^{-}} \frac{\left[\mathrm{SO}_{4}^{2-}\right] \cdot \gamma_{\mathrm{SO}_{4}^{2-}} \cdot\left[\mathrm{H}^{+}\right] \cdot \gamma_{\mathrm{H}^{+}}}{\left[\mathrm{HSO}_{4}^{-}\right] \cdot \gamma_{\mathrm{HSO}_{4}^{-}}} \\
& { }^{x} K_{\mathrm{SO}_{3}}=\frac{\chi_{\mathrm{H}_{2} \mathrm{SO}_{4}} \cdot f_{\mathrm{H}_{2} \mathrm{SO}_{4}}}{\chi_{\mathrm{SO}_{3}} \cdot f_{\mathrm{SO}_{3}} \cdot \chi_{\mathrm{H}_{2} \mathrm{O}} \cdot f_{\mathrm{H}_{2} \mathrm{O}}} \\
& K_{\mathrm{NH}_{3}} \frac{\left[\mathrm{NH}_{3}\right] \cdot \gamma_{\mathrm{NH}_{3}} \cdot\left[\mathrm{H}^{+}\right] \cdot \gamma_{\mathrm{H}^{+}}}{\left[\mathrm{NH}_{4}^{+}\right] \cdot \gamma_{\mathrm{NH}_{4}^{+}}} \\
& n_{\mathrm{S}(\mathrm{VI})}=n_{\mathrm{H}_{2} \mathrm{SO}_{4}}+n_{\mathrm{HSO}_{4}^{-}}+n_{\mathrm{SO}_{4}^{2-}}+n_{\mathrm{SO}_{3}} \\
& n_{\mathrm{N}(-\mathrm{III})}=n_{\mathrm{NH}_{4}^{+}}+n_{\mathrm{NH}_{3}}
\end{aligned}
$$

The thermodynamic equilibrium coefficients for $\mathrm{H}_{2} \mathrm{SO}_{4}$ and $\mathrm{HSO}_{4}^{-}$dissociations and $\mathrm{NH}_{3}$ protonation (Eqs. 3, 4 and 6) are given in a molality-based form while the equilibrium coefficient in Eq. (5), which involves the equilibration between the different solvents $\left(\mathrm{H}_{2} \mathrm{O}, \mathrm{SO}_{3}\right.$ and $\left.\mathrm{H}_{2} \mathrm{SO}_{4}\right)$, is given in a mole-fraction-based form. The Eq. (5) is given in a molefraction-based form for the following reasons: (a) the eNRTL provides mole-fraction-based activity coefficients, and (b) if Eq. (5) were to be applied for $a_{\mathrm{w}}$ that are even lower than considered in this work, the assumption of using molalities, i.e. where water is considered to be the only solvent, would not be acceptable. The model calculates $K_{\mathrm{HSO}_{4}^{-}}$and $K_{\mathrm{NH}_{3}}$ (mol kg${ }^{-1}$ ) with Eqs. (9) and (10) (Jacobson, 2005). We treat $K_{\mathrm{H}_{2} \mathrm{SO}_{4}}$ and ${ }^{x} K_{\mathrm{SO}_{3}}$ as unknown model fitting parameters.

$$
\begin{aligned}
& K_{\mathrm{H}_{2} \mathrm{SO}_{4}}=1.015 \times 10^{-2} \\
& \cdot e^{\left(8.85 \cdot\left(\frac{298}{T}-1\right)+25.14 \cdot\left(1+\ln \left(\frac{298}{T}\right)-\frac{298}{T}\right)\right)} \\
& K_{\mathrm{NH}_{3}}=1.7882 \cdot 10^{9} \cdot e^{21.02 \cdot\left(\frac{298}{T}-1\right)}
\end{aligned}
$$

Once $\left[\mathrm{H}^{+}\right]$is determined, all other ion and molecule concentrations can be derived from Eqs. (2)-(8). Based on the new estimated particle-phase ion and molecule mole fractions, the thermodynamic model uses AIOMFAC and eNRTL to update the ion and molecule activity coefficients. The model then repeats the whole procedure iteratively until the relative change in the concentration and activity coefficients for each compound is less than $10^{-9}$ between successive iteration steps. To stabilise convergence, the model estimates activity coefficients used in the proceeding iteration as a weighted average of the values from the previous and present iteration time steps.

\subsection{3 $\quad \mathrm{H}_{2} \mathrm{SO}_{4}$ and $\mathrm{SO}_{3}$ in the gas phase}

In the gas phase only a fraction of $\mathrm{H}_{2} \mathrm{SO}_{4}$ is in the form of pure sulfuric acid molecules while the rest of the $\mathrm{H}_{2} \mathrm{SO}_{4}$ is in a hydrated form. In this work we use the parameterisation from Hanson and Eisele (2000), who measured the diffusion loss rate of $\mathrm{H}_{2} \mathrm{SO}_{4}$ to flow-tube walls at different $\mathrm{RH}$, to estimate the RH-dependent effective diffusion coefficient of $\mathrm{H}_{2} \mathrm{SO}_{4}(\mathrm{~g})$.

In the gas phase, $\mathrm{SO}_{3}$ reacts rapidly with $\mathrm{H}_{2} \mathrm{O}$ to form $\mathrm{H}_{2} \mathrm{SO}_{4}$. Based on the measured loss rate of $\mathrm{SO}_{3}$, which shows a second-order dependence on the water vapour concentration (Jayne et al., 1997), we estimate that $\mathrm{SO}_{3}(\mathrm{~g})$ is converted to $\mathrm{H}_{2} \mathrm{SO}_{4}(\mathrm{~g})$ in less than $1 \mathrm{~s}$ during the CLOUD chamber experiments, even at the lowest RH. Because of this rapid conversion to $\mathrm{H}_{2} \mathrm{SO}_{4}$ and the high vapour pressure of $\mathrm{SO}_{3}$ (Eq. 12), it is reasonable to assume that the gas-phase concentration of $\mathrm{SO}_{3}$ (vapour pressure, $p_{\infty, \mathrm{SO}_{3}(\mathrm{~g})}$ ) is negligibly low.

\subsubsection{Saturation vapour pressures, surface tension and particle density}

We use Eqs. (11) and (12) to calculate the temperaturedependent sub-cooled pure-liquid saturation vapour pressures for $\mathrm{H}_{2} \mathrm{SO}_{4}$ and $\mathrm{SO}_{3}\left(p_{0, i}\right.$, where $i$ refers to $\mathrm{H}_{2} \mathrm{SO}_{4}$ or $\mathrm{SO}_{3}$ in $\mathrm{Pa}$ ). Equation (11) is based on the work of Ayers et al. (1980), with corrections for lower temperatures by Kulmala and Laaksonen (1990). We use the (best fit) $L$ parameter value of -11.695 (Noppel et al., 2002, NoppelKulmala-Laaksonen, N-K-L, parameterisation; see Supplement Fig. S5a). Equation (12) is based on the work of Nickless (1968) (see Supplement Fig. S5b).

$$
\begin{aligned}
& p_{0, \mathrm{H}_{2} \mathrm{SO}_{4}}=101325 \\
& \cdot e^{\left(L+10156 \cdot\left[\frac{1}{360.15}-\frac{1}{T}+\frac{0.38}{545} \cdot\left(1+\ln \left(\frac{360.15}{T}\right)-\frac{360.15}{T}\right)\right]\right)} \\
& p_{0, \mathrm{SO}_{3}}=e^{\left(28.9239-\frac{7000}{T}\right) \cdot 133.3224}
\end{aligned}
$$

As an alternative to Eqs. (11) and (12) we also use the $\mathrm{H}_{2} \mathrm{SO}_{4}$ and $\mathrm{SO}_{3}$ pure-liquid saturation vapour pressure parameterisations from Que et al. (2011) (originally from the Aspen Plus Databank, Fig. S5).

We calculate the saturation vapour pressures of $\mathrm{H}_{2} \mathrm{SO}_{4}$ and $\mathrm{SO}_{3}$ for each particle size with Eq. (13), using the mole fractions $\left(\chi_{i, j}\right)$ and mole-fraction-based activity coefficients $\left(f_{i, j}\right)$ of $\mathrm{H}_{2} \mathrm{SO}_{4}$ and $\mathrm{SO}_{3}$ (from the thermodynamic model) and the Kelvin term, $C_{k, i, j}$ Eq. (14) for compound $i$ in particle size bin $j$.

$p_{s, i, j}=p_{0, i} \cdot a_{i, j} \cdot C_{k, i, j}$,

where $a_{i, j}=\chi_{i, j} \cdot f_{i, j}$

$C_{k, i, j}=e^{\left(\frac{4 \cdot M_{\mathrm{i}} \cdot \sigma_{j}}{R \cdot T \cdot \rho_{p, j} \cdot D_{p, j}}\right)}$.

$a_{i, j}$ is the activity of compound $i$ in size bin $j, T$ is the temperature in kelvin, $R$ is the universal gas constant $\left(\mathrm{J} \mathrm{mol}^{-1} \mathrm{~K}^{-1}\right), M_{\mathrm{i}}$ is the molar mass $\left(\mathrm{kg} \mathrm{mol}^{-1}\right)$ of compound $i, \rho_{p, j}$ is the density $\left(\mathrm{kg} \mathrm{m}^{-3}\right)$ of the liquid particles, 
$\sigma_{j}$ is the surface tension $\left(\mathrm{N} \mathrm{m}^{-1}\right)$ and $D_{p, j}$ is the diameter (m) of the particles in size bin $j$.

As an alternative approach we also model the evaporation of $\mathrm{H}_{2} \mathrm{SO}_{4}$ using composition-dependent $\mathrm{H}_{2} \mathrm{SO}_{4}$ activ-

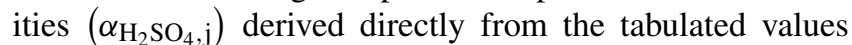
of the difference in chemical potentials between the sulphuric acid in aqueous solution and that of the pure acid $\left(\mu_{\mathrm{H}_{2} \mathrm{SO}_{4}, \mathrm{j}}-\mu_{\mathrm{H}_{2} \mathrm{SO}_{4}}^{0}\right)$. The tabulated values that are valid at $298.15 \mathrm{~K}$ are taken from Giauque et al. (1960). The relationship between $\mu_{\mathrm{H}_{2} \mathrm{SO}_{4}, \mathrm{j}}-\mu_{\mathrm{H}_{2} \mathrm{SO}_{4}}^{0}$ and $\alpha_{\mathrm{H}_{2} \mathrm{SO}_{4}, \mathrm{j}}$ is given by Eq. (15).

$\ln \left(a_{\mathrm{H}_{2} \mathrm{SO}_{4}, \mathrm{j}}\right)=\left(\mu_{\mathrm{H}_{2} \mathrm{SO}_{4}, \mathrm{j}}-\mu_{\mathrm{H}_{2} \mathrm{SO}_{4}}^{0}\right) /(R \cdot T)$

In accordance with Ayers et al. (1980) we neglect any temperature dependence of $\mu_{\mathrm{H}_{2} \mathrm{SO}_{4}, \mathrm{j}}-\mu_{\mathrm{H}_{2} \mathrm{SO}_{4}}^{0}$. This empirically based approach is used in several chemistry transport models to simulate the evaporation of pure sulfuric acid particle in the stratosphere (see, e.g., Kokkola et al., 2009; English et al., 2011; Hommel et al., 2011).

We calculate the surface tension and density of the particles comprising a ternary mixture of water, sulfuric acid and ammonium with parameterisations given by Hyvärinen et al. (2005) that combine surface tension parameterisations for $\left(\mathrm{NH}_{4}\right)_{2} \mathrm{SO}_{4}-\mathrm{H}_{2} \mathrm{O}$ mixtures (Hämeri et al., 2000; Korhonen et al., 1998b), $\mathrm{H}_{2} \mathrm{SO}_{4}-\mathrm{H}_{2} \mathrm{O}$ mixtures (Vehkamäki et al., 2002) and $\mathrm{NH}_{3}-\mathrm{H}_{2} \mathrm{O}$ mixtures (King et al., 1930). For the range of conditions in our experiments the minimum particle diameter after evaporation is $\sim 50( \pm 10) \mathrm{nm}$ (for experiments 1 and 2). The Kelvin effect only increases the water saturation vapour pressure by maximum value of 1.07 (and the $\mathrm{H}_{2} \mathrm{SO}_{4}$ saturation vapour pressure by 1.44 ; see Supplement Fig. S6) for the particle diameter of $40 \mathrm{~nm}$.

\subsubsection{Evaporation of $\mathrm{H}_{2} \mathrm{SO}_{4}, \mathrm{SO}_{3}$ and $\mathrm{H}_{2} \mathrm{O}$}

We model the gas-particle partitioning (evaporation) of $\mathrm{H}_{2} \mathrm{SO}_{4}$ and $\mathrm{SO}_{3}$ using the full moving size distribution method in combination with the Analytic Prediction of Condensation (APC) scheme (Jacobson, 2005). APC is an unconditionally stable numerical discretisation scheme used to solve the condensation equation, Eq. (16). In Eq. (16), we substitute the saturation vapour pressures from Eq. (13) and

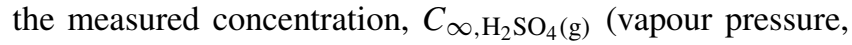
$\left.p_{\infty, \mathrm{H}_{2} \mathrm{SO}_{4}(\mathrm{~g})}\right)$ of $\mathrm{H}_{2} \mathrm{SO}_{4(\mathrm{~g})}$. Based on the motivation given in Sect. 3.3.3 the vapour pressure of $\mathrm{SO}_{3}, p_{\infty, \mathrm{SO}_{3}(\mathrm{~g})}$, is set to zero.

$$
\begin{aligned}
& \frac{d m_{i, j}}{\mathrm{~d} t}=\frac{2 \cdot \pi \cdot\left(d_{\mathrm{i}}+d_{j}\right) \cdot\left(D_{\mathrm{i}}+D_{j}\right) \cdot M_{\mathrm{i}}}{R \cdot T} \\
& \cdot \beta_{i, j}\left(K n_{i, j}, \alpha_{\mathrm{i}}\right) \cdot\left(p_{\infty, i}-p_{s, i, j}\right) \\
& \beta_{i, j}\left(K n_{i, j}, \alpha_{\mathrm{i}}\right)= \\
& \frac{K n_{i, j}+1}{0.377 \cdot K n_{i, j}+1+\frac{4}{3 \cdot \alpha_{\mathrm{i}}} \cdot\left(K n_{i, j}^{2}+K n_{i, j}\right)} \\
& K n_{i, j}=\frac{2 \cdot \lambda_{i, j}}{d_{\mathrm{i}}+d_{j}}, \quad \lambda_{i, j}=\frac{3 \cdot\left(D_{\mathrm{i}}+D_{j}\right)}{\sqrt{v_{\mathrm{i}}^{2}+v_{j}^{2}}}
\end{aligned}
$$

Equation (16) describes the contribution of species $i$ to the mass growth rate of a particle in size bin $j, \beta_{i, j}$ is the Fuchs-Sutugin correction factor in the transition region (Fuchs and Sutugin, 1971), $d_{\mathrm{i}}, d_{j}$ correspond to diameters (m) and $D_{\mathrm{i}}, D_{j}$ to diffusion coefficients $\left(\mathrm{m}^{2} \mathrm{~s}^{-1}\right)$ of the condensing molecule $i$ and the particles in size bin $j$, respectively. $\alpha_{i}$ is the mass-accommodation coefficient of compound $i$ and $K n_{i, j}$ is the non-dimensional Knudsen number, Eq. (17). $\lambda_{i, j}$ is the mean free path (m) and $v_{i}$ and $v_{j}$ are the thermal speeds $\left(\mathrm{m} \mathrm{s}^{-1}\right)$ of the molecule $i$ and the particles in size bin $j$, respectively. Equations (16) and (17) take into account that the condensing molecules have a nonnegligible size compared to the size of the smallest particles, and that small particles have non-negligible diffusion coefficients (Lehtinen and Kulmala, 2003).

Based on measurements of $\mathrm{H}_{2} \mathrm{SO}_{4}$ losses in a flow tube reactor, Pöschl et al. (1998) derived a mass accommodation coefficient of $\mathrm{H}_{2} \mathrm{SO}_{4(\mathrm{~g})}$ on aqueous sulfuric acid, which was close to unity, with a best fit value of 0.65 , a lower limit value of 0.43 and an upper limit of 1.38 (physical limit 1.0). The measured mass accommodation coefficients do not show any dependence on the relative amount of water in the particles (Pöschl et al., 1998). For the model simulations in this work we use unity mass accommodation coefficients. The particle water content is modelled as an equilibrium process with the thermodynamic model (see Sect. 3.3.2).

\subsubsection{Particle losses}

The electric field strength of the stainless-steel CLOUD chamber, in contrast to smog chambers made of Teflon, is very low. Therefore, we can neglect electrostatic deposition enhancements (for details on how ADCHAM treats particle wall deposition losses see Roldin et al., 2014). We simulate the particle-size-dependent deposition losses with the model from Lai and Nazaroff (2000). The particle deposition loss depends on the friction velocity $\left(u^{*}\right)$, which we treat as an unknown model fitting parameter. The best possible agreement between the modelled and measured particle number and volume concentration in the chamber is achieved with a friction velocity of $\sim 0.2 \mathrm{~m} \mathrm{~s}^{-1}$. Thus, for all model results we present in this article we use $u^{*}=0.2 \mathrm{~m} \mathrm{~s}^{-1}$. Dilution 
losses due to the purified air injected to the CLOUD chamber are also considered in the model.

\subsubsection{Constraining the thermodynamic properties of sulfate aerosol particles}

We use ADCHAM to constrain the values of the thermodynamic equilibrium coefficients, $K_{\mathrm{H}_{2} \mathrm{SO}_{4}}$ and ${ }^{x} K_{\mathrm{SO}_{3}}$, by treating these coefficients as unknown model fitting parameters. By varying the equilibrium coefficients we search for the best possible agreement (coefficient of determination $\left(R^{2}\right)$; see Supplement, Table S1) between the modelled and measured geometric mean diameter (GMD) with respect to particle number. Because experimental results reveal that the sulfate particles did not evaporate completely, they must have been contaminated with a small fraction of effectively nonvolatile material (Sect. 3.2).

In the model we address this by assuming either that the particles (prior to evaporation) contained a small fraction of non-volatile organic material (e.g. secondary organic aerosol, SOA) or that the particles contained small amounts of ammonium, which prevented pure $\mathrm{H}_{2} \mathrm{SO}_{4}$ particle formation and consequently prevented the evaporation. We calculate the initial SOA and ammonium dry particle volume fraction in particle size bin $j\left(\chi_{\mathrm{SOA}, j}^{v}\right.$ and $\left.\chi_{\mathrm{NH}_{4}^{+}, j}^{v}\right)$ with Eqs. (19) and (20), respectively. Here $d_{\mathrm{SOA}}$ and $d_{\mathrm{NH}_{4}}^{+}$represent an effective particle diameter of SOA and ammonium if all other particle species are removed. For experiment 1 we use $d_{\text {SOA }}=$ $60 \mathrm{~nm}$ and $d_{\mathrm{NH}_{4}}^{+}=26 \mathrm{~nm}$, for experiment $2 d_{\mathrm{SOA}}=43 \mathrm{~nm}$ and $d_{\mathrm{NH}_{4}}^{+}=19 \mathrm{~nm}$ and for experiment $3 d_{\mathrm{SOA}}=38 \mathrm{~nm}$ and $d_{\mathrm{NH}_{4}}^{+}=17 \mathrm{~nm}$.

$$
\begin{aligned}
& \chi_{\mathrm{SOA}, j}^{v}=\min \left(\frac{d_{\mathrm{SOA}}^{3}}{d_{j}^{3}}, 0.2\right) \\
& \chi_{\mathrm{NH}_{4}^{+}, \mathrm{j}}^{v}=\min \left(\frac{d_{\mathrm{NH}_{4}^{+}}^{3}}{d_{j}^{3}}, 0.05\right)
\end{aligned}
$$

\section{Results and discussion}

In order to fit the modelled particle number size distribution evolution to the observations we performed several hundred simulations where we varied $K_{\mathrm{H}_{2} \mathrm{SO}_{4}}$ and ${ }^{x} K_{\mathrm{SO}_{3}}$. We summarise these simulations into three main categories (cases):

- Case 1: only $\mathrm{H}_{2} \mathrm{SO}_{4}$ and $\mathrm{H}_{2} \mathrm{O}$ evaporation $\left({ }^{x} K_{\mathrm{SO}_{3}}=\right.$ $\infty)$

- Case 2: a combination of $\mathrm{H}_{2} \mathrm{SO}_{4}, \mathrm{H}_{2} \mathrm{O}$ and $\mathrm{SO}_{3}$ evaporation.

- Case 3: practically only $\mathrm{SO}_{3}$ and $\mathrm{H}_{2} \mathrm{O}$ evaporation.

Case 2 is further divided into two subcategories, Case $2 \mathrm{a}$ and 2b. In Case $2 \mathrm{a}$ the $\mathrm{H}_{2} \mathrm{SO}_{4}$ is the dominant evaporating $\mathrm{S}(\mathrm{VI})$ (a)

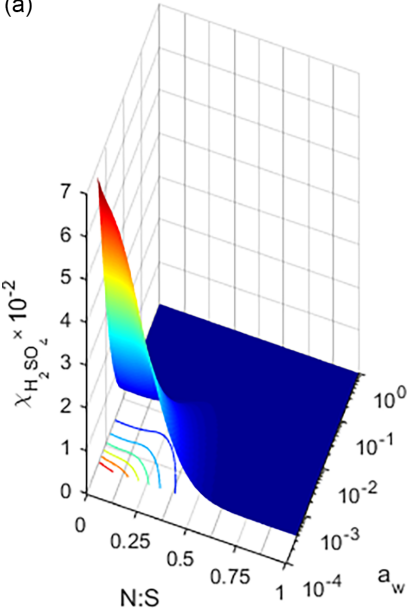

(b)

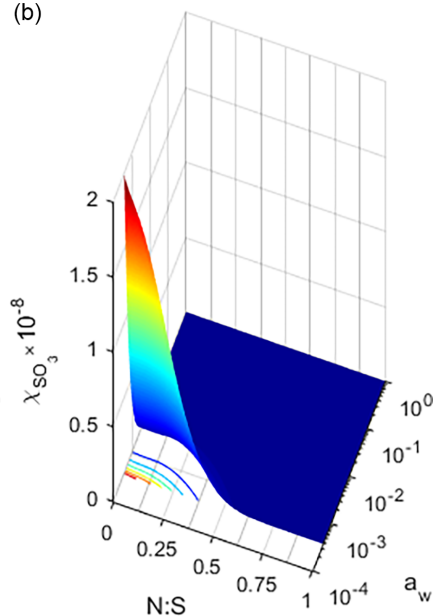

Figure 2. Modelled particle-phase mole fractions of (a) $\mathrm{H}_{2} \mathrm{SO}_{4}$ (aq), $\chi_{\mathrm{H}_{2} \mathrm{SO}_{4}}$, and (b) $\mathrm{SO}_{3(\mathrm{aq})}, \chi_{\mathrm{SO}_{3}}$, as a function of the water activity $\left(a_{\mathrm{w}}\right)$ and the $\mathrm{N}: \mathrm{S}$ for Case $2 \mathrm{a}$ which represents the combination of $\mathrm{H}_{2} \mathrm{SO}_{4}, \mathrm{H}_{2} \mathrm{O}$ and $\mathrm{SO}_{3}$ evaporating species with $\mathrm{H}_{2} \mathrm{SO}_{4}$ being the dominating evaporating $\mathrm{S}(\mathrm{VI})$ species. The colour-coded contours on the $x-y$ axes represent constant particle-phase mole fractions for (a) $\chi_{\mathrm{H}_{2} \mathrm{SO}_{4}}=1-6 \times 10^{-2}$ and (b) $\chi_{\mathrm{SO}_{3}}=0.3-1.8 \times 10^{-8}$. The equilibrium coefficients are $K_{\mathrm{H}_{2} \mathrm{SO}_{4}}=2.40 \times 10^{9} \mathrm{~mol} \mathrm{~kg}^{-1}$, and ${ }^{x} K_{\mathrm{SO}_{3}}=1.43 \times 10^{10}$ at $T=288.8 \mathrm{~K}$.

species while in Case $2 \mathrm{~b}$ the $\mathrm{SO}_{3}$ is the dominant evaporating $\mathrm{S}(\mathrm{VI})$ species.

\subsection{Particle-phase mole fractions}

Figure 2 shows an example of the modelled mole fractions of (a) $\mathrm{H}_{2} \mathrm{SO}_{4(\mathrm{aq})}, \chi_{\mathrm{H}_{2} \mathrm{SO}_{4}}$, and (b) $\mathrm{SO}_{3 \text { (aq) }}, \chi_{\mathrm{SO}_{3}}$, as a function of the $a_{\mathrm{w}}$ and $\mathrm{N}: \mathrm{S}$ for Case $2 \mathrm{a}$ with equilibrium constants $K_{\mathrm{H}_{2} \mathrm{SO}_{4}}=2.40 \times 10^{9} \mathrm{~mol} \mathrm{~kg}^{-1}$, and ${ }^{x} K_{\mathrm{SO}_{3}}=1.43 \times 10^{10}$ at $T=288.8 \mathrm{~K}$. Figure 2 reveals that the increase in $\chi_{\mathrm{SO}_{3}}$ as $a_{\mathrm{w}}$ decreases is steeper than for $\chi_{\mathrm{H}_{2} \mathrm{SO}_{4}}$. This is because $\mathrm{H}_{2} \mathrm{SO}_{4}$ (aq) formation precedes $\mathrm{SO}_{3}$ formation (see Reaction R3). As expected, the highest values of $\chi_{\mathrm{H}_{2} \mathrm{SO}_{4}}$ and $\chi_{\mathrm{SO}_{3}}$ occur when $\mathrm{N}: \mathrm{S}=0$ and $a_{\mathrm{w}}$ approaches zero. While $\mathrm{N}: \mathrm{S}$ increases, $\chi_{\mathrm{H}_{2} \mathrm{SO}_{4}}$ and $\chi_{\mathrm{SO}_{3}}$ decrease gradually and reach lower values when $\mathrm{N}: \mathrm{S}$ becomes larger than 0.6 .

\subsection{Particle number size distribution evolution}

In Fig. 3 we present the particle number size distribution evolution after the shutter of the UV light is closed and the influx of water vapour to the chamber is interrupted for experiment 2, performed at $T=288.8 \mathrm{~K}$, showing (a) the measured and (b) the modelled values for Case 2a with $K_{\mathrm{H}_{2} \mathrm{SO}_{4}}=$ $2.40 \times 10^{9} \mathrm{~mol} \mathrm{~kg}^{-1}$ and ${ }^{x} K_{\mathrm{SO}_{3}}=1.43 \times 10^{10}$. At the beginning of the evaporation process the particles in the size range from $\sim 60$ to $\sim 180 \mathrm{~nm}$ in diameter contain approximately 70 mole $\% \mathrm{H}_{2} \mathrm{O}$; however, this percentage decreases, declining to 15 mole $\%$ after $6 \mathrm{~h}$ (Fig. $3 \mathrm{c}$ ). Before $\mathrm{H}_{2} \mathrm{SO}_{4}$ and $\mathrm{SO}_{3}$ 

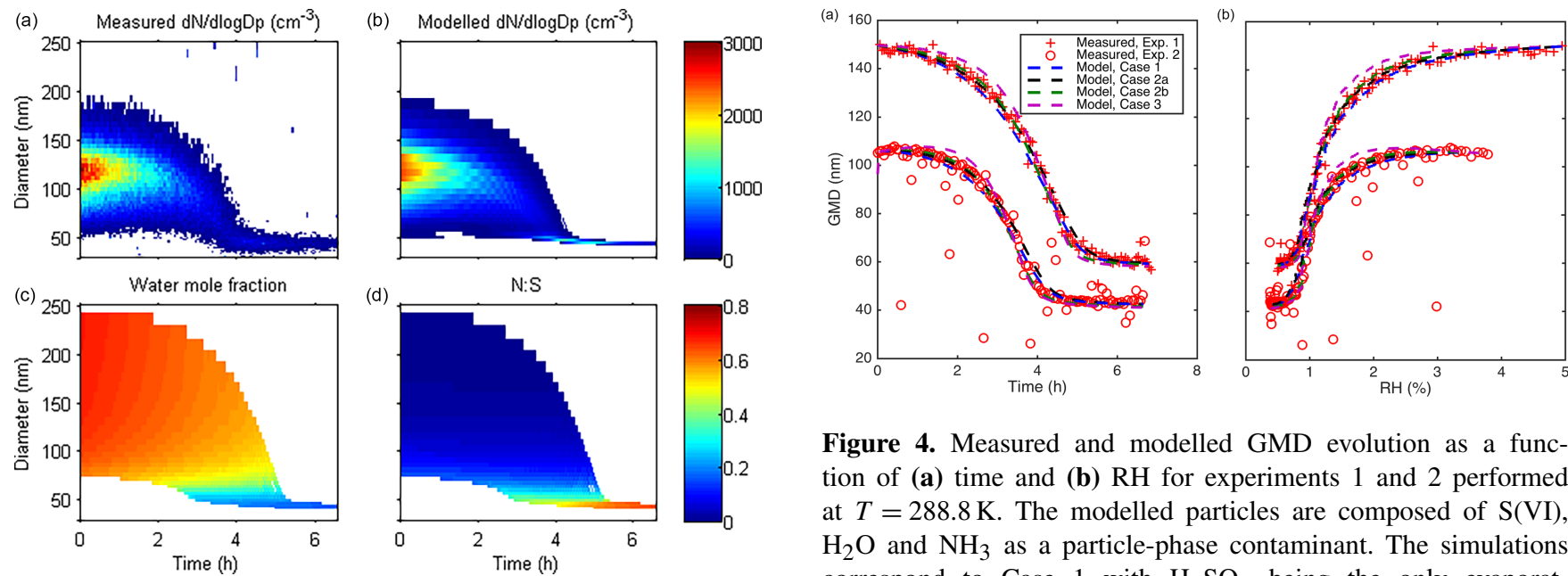

Figure 4. Measured and modelled GMD evolution as a function of (a) time and (b) RH for experiments 1 and 2 performed at $T=288.8 \mathrm{~K}$. The modelled particles are composed of $\mathrm{S}(\mathrm{VI})$, $\mathrm{H}_{2} \mathrm{O}$ and $\mathrm{NH}_{3}$ as a particle-phase contaminant. The simulations correspond to Case 1 with $\mathrm{H}_{2} \mathrm{SO}_{4}$ being the only evaporating $\mathrm{S}(\mathrm{VI})$ species, $K_{\mathrm{H}_{2} \mathrm{SO}_{4}}=2.00 \times 10^{9} \mathrm{~mol} \mathrm{~kg}^{-1}$; Case $2 \mathrm{a}$ with $\mathrm{H}_{2} \mathrm{SO}_{4}$ being the dominating evaporating $\mathrm{S}(\mathrm{VI})$ species, $K_{\mathrm{H}_{2} \mathrm{SO}_{4}}=$ $2.40 \times 10^{9} \mathrm{~mol} \mathrm{~kg}^{-1}$ and ${ }^{x} K_{\mathrm{SO}_{3}}=1.43 \times 10^{10}$; Case $2 \mathrm{~b}$ with $\mathrm{SO}_{3}$ being the dominating evaporating $\mathrm{S}(\mathrm{VI})$ species, $K_{\mathrm{H}_{2} \mathrm{SO}_{4}}=$ $4.00 \times 10^{9} \mathrm{~mol} \mathrm{~kg}^{-1}$ and ${ }^{x} K_{\mathrm{SO}_{3}}=1.54 \times 10^{9}$; and Case 3 with $\mathrm{SO}_{3}$ being the only evaporating $\mathrm{S}(\mathrm{VI})$ species, $K_{\mathrm{H}_{2} \mathrm{SO}_{4}}=$ $1.00 \times 10^{11} \mathrm{~mol} \mathrm{~kg}^{-1}$ and ${ }^{x} K_{\mathrm{SO}_{3}}=3.33 \times 10^{7}$ (see Supplement, Table S1, simulations 1-4 and 13-16). The pure-liquid saturation vapour pressures of $\mathrm{H}_{2} \mathrm{SO}_{4}$ and $\mathrm{SO}_{3}$ are calculated with Eq. (11), N-K-L parameterisation (Kulmala and Laaksonen, 1990; Noppel et al., 2002), and Eq. (12) (Nickless, 1968), respectively.

tion of ammonium is very low (Fig. 3d). However, during the evaporation process $\mathrm{N}: \mathrm{S}$ increases steadily until it reaches a value of $\sim 0.6$ after $\sim 6 \mathrm{~h}$. At this point the particles are $\sim 40 \mathrm{~nm}$ in diameter and do not shrink further. This model result is in good agreement with the experimental results reported by Marti et al. (1997) and confirms that $\mathrm{NH}_{4}^{+}$effectively stabilises sulfur particles against evaporation when $\mathrm{N}: \mathrm{S} \approx 0.6$. Thus, in the stratosphere, even small amounts of a base (such as $\mathrm{NH}_{3}$ ) can prevent the sulphate particles from shrinking.

\subsection{Geometric mean diameter shrinkage influenced by relative humidity}

Figure 4 compares the measured and modelled GMD evolution as a function of (a) time and (b) RH for experiments 1 and 2 performed at a temperature of $T=288.8 \mathrm{~K}$ (Table 1) with $\mathrm{NH}_{3}$ as a particle-phase contaminant (see Supplement, Table S1, simulations $1-4$ and 13-16). The pure-liquid saturation vapour pressures of $\mathrm{H}_{2} \mathrm{SO}_{4}$ and $\mathrm{SO}_{3}$ are calculated with Eqs. (11) and (12). The model results are in good agreement with the measured GMD trend for Case $1\left(K_{\mathrm{H}_{2} \mathrm{SO}_{4}}=2.00 \times 10^{9} \mathrm{~mol} \mathrm{~kg}^{-1}\right)$, Case $2 \mathrm{a}\left(K_{\mathrm{H}_{2} \mathrm{SO}_{4}}=\right.$ $2.40 \times 10^{9} \mathrm{~mol} \mathrm{~kg}^{-1}$ and ${ }^{x} K_{\mathrm{SO}_{3}}=1.43 \times 10^{10}$ ), Case $2 \mathrm{~b}$ $\left(K_{\mathrm{H}_{2} \mathrm{SO}_{4}}=4.00 \times 10^{9} \mathrm{~mol} \mathrm{~kg}^{-1}\right.$ and $\left.{ }^{x} K_{\mathrm{SO}_{3}}=1.54 \times 10^{9}\right)$ and Case $3\left(K_{\mathrm{H}_{2} \mathrm{SO}_{4}}=1.00 \times 10^{11} \mathrm{~mol} \mathrm{~kg}^{-1}\right.$ and ${ }^{x} K_{\mathrm{SO}_{3}}=$ $3.33 \times 10^{7}$ ). The Case 3 simulations give a particle shrinkage that begins somewhat too late and occurs somewhat too rapidly. However, considering the measurement uncertain-

ties it is impossible to constrain the relative contribution of $\mathrm{H}_{2} \mathrm{SO}_{4}$ and $\mathrm{SO}_{3}$ to the observed GMD loss only based on these two experiments (see Sect. 4.4).

With the Aspen Plus Databank pure-liquid saturation vapour pressure parameterisations it is also possible to find similarly good agreement between the modelled and observed GMD evolution during experiment 1 and 2 for cases 1, 2a, $2 \mathrm{~b}$ and 3 (Fig. S8) with $\mathrm{NH}_{3}$ as the particle-phase contaminant, but with somewhat different values of $K_{\mathrm{H}_{2} \mathrm{SO}_{4}}$ and ${ }^{x} \mathrm{~K}_{\mathrm{SO}_{3}}$ (see Supplement, Table S1, simulations 8-11 and 2023).

The model simulations with non-volatile and non-watersoluble organics or dimethylamine (DMA) as the particlephase contaminant give nearly identical results to those with $\mathrm{NH}_{3}$, both for experiments 1 and 2 (see Supplement Table S1, simulations 6, 7, 17 and 18). In the case of DMA this occurs because it is also a strong enough base to be completely protonated (all $\mathrm{N}(-\mathrm{III})$ is in the form of $\mathrm{NH}_{4}^{+}$). In the case of an organic contaminant instead of $\mathrm{NH}_{3}$ the model results mainly differ at a later stage of the particle evaporation phase when the $\mathrm{N}: \mathrm{S}$ approaches $\sim 0.5$. This is because the evaporation rate does not slow down before all $\mathrm{S}(\mathrm{VI})$ is lost when the particles do not contain any base (see Fig. S9). Thus, the modelled GMD shrinkage becomes somewhat faster when assuming organic contamination. Without any particle-phase contamination (pure sulfuric acid parti- 
cles) the particles evaporate faster and completely (see Supplement, Fig. S10).

Instead of explicitly calculating the $\mathrm{H}_{2} \mathrm{SO}_{4}$ activity with the thermodynamic model we derive it directly from the tabulated values of the $\mathrm{H}_{2} \mathrm{SO}_{4}$ chemical potentials as a function of the molality, following Giauque et al. (1960), Eq. (15). With this method we simulate the evaporation of $\mathrm{H}_{2} \mathrm{SO}_{4}$ without explicitly calculating the concentration of $\mathrm{H}_{2} \mathrm{SO}_{4}$ in the particles. However, since the tabulated chemical potentials from Giauque et al. (1960) are only valid for pure sulfuric acid solutions and temperatures close to $298.15 \mathrm{~K}$, it cannot be used if the particle aqueous phase also contains ammonium or other stabilising molecules.

Based on data from Giauque et al. (1960), Eq. (15) and the pure-liquid saturation vapour pressure parameterisation, Eq. (11) (N-K-L parameterisation), the modelled GMD shrinkage is consistent with the observations for experiments 1 and 2 when we consider the Case $1\left(\mathrm{H}_{2} \mathrm{SO}_{4}\right.$ as the only evaporating $\mathrm{S}(\mathrm{VI})$ species) and particle-phase contamination due to non-volatile non-water-soluble organics (see Supplement, Fig. S11 and Table S1, simulations 5, 12, 19 and 24). However, when we use the pure-liquid saturation vapour pressure parameterisation from the Aspen Plus Databank, the modelled particles evaporate earlier (at higher RH) than the observed particles. The reason is that the ASPEN compared to $\mathrm{N}-\mathrm{K}-\mathrm{L}$ parameterisation gives higher saturation vapour pressures (see Supplement, Fig. S5).

\subsection{Geometric mean diameter shrinkage influenced by relative humidity and temperature}

In an attempt to constrain how $K_{\mathrm{H}_{2} \mathrm{SO}_{4}}$ and ${ }^{x} K_{\mathrm{SO}_{3}}$ depend on the temperature, and the role of $\mathrm{H}_{2} \mathrm{SO}_{4}$ and $\mathrm{SO}_{3}$ on the observed particle diameter shrinkage, as a next step we simulate experiment 3 , which expands in temperature. For this experiment the temperature increases gradually from 268 to $293 \mathrm{~K}$, while the absolute humidity remains at a constant value, thus allowing the RH to decrease. Equation (21) describes the modelled temperature dependence of $K_{\mathrm{H}_{2} \mathrm{SO}_{4}}$ and ${ }^{x} K_{\mathrm{SO}_{3}}$, where the $K_{\mathrm{i}}$ values at $T=288.8 \mathrm{~K}\left(K_{i, 288.8 \mathrm{~K}}\right)$ set equal to the values in regard to the model simulations of experiments 1 and 2 (Sect. 4.3):

$K_{\mathrm{i}}=K_{i, 288.8 \mathrm{~K}} \cdot e^{\left(B_{\mathrm{i}}\left(\frac{1}{T}-\frac{1}{288.8}\right)\right)}$,

where $i$ can be either $\mathrm{H}_{2} \mathrm{SO}_{4}$ or $\mathrm{SO}_{3}$. With $B_{\mathrm{i}}=0 \mathrm{~K}$ there is no temperature dependence of $K_{\mathrm{i}}$.

For other acids like $\mathrm{HNO}_{3}, \mathrm{HCl}$ and $\mathrm{HSO}_{4}^{-}, K_{\mathrm{i}}$ decreases with increasing $T\left(B_{\mathrm{i}}>0\right)$ (Jacobson, 2005). Que et al. (2011) estimate $B_{\mathrm{H}_{2} \mathrm{SO}_{4}}$ to be $3475 \mathrm{~K}$ and $B_{\mathrm{SO}_{3}}$ to be $14245.7 \mathrm{~K}$. Thus, based on this information we would expect the equilibrium Reactions (R1) and (R3) to shift towards the left (more $\mathrm{H}_{2} \mathrm{SO}_{4(\mathrm{aq})}$ and $\mathrm{SO}_{3}$ as temperature increases). This would result in a stronger temperature dependence of the $\mathrm{H}_{2} \mathrm{SO}_{4(\text { aq) }}$ and $\mathrm{SO}_{3}$ saturation vapour pressures over aqueous

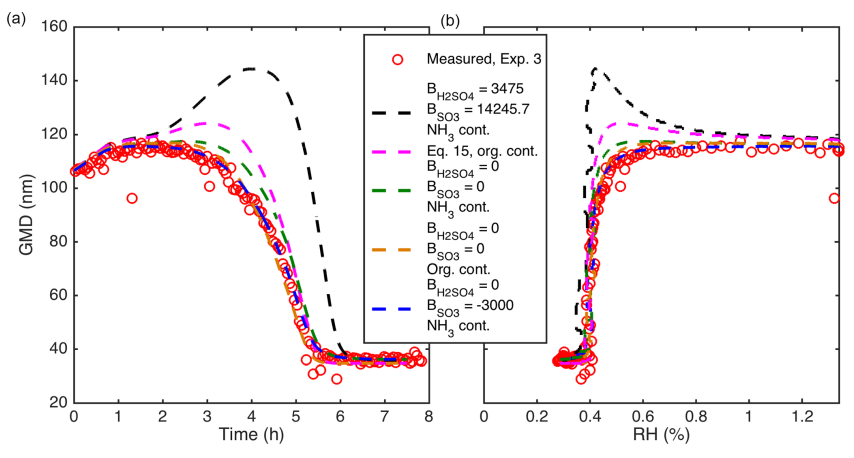

Figure 5. Measured and modelled GMD evolution as a function of (a) time and (b) $\mathrm{RH}$ for experiment 3 performed at a temperature range from 268 to $293 \mathrm{~K}$. The modelled particles are composed of $\mathrm{S}(\mathrm{VI}), \mathrm{H}_{2} \mathrm{O}$ and either $\mathrm{NH}_{3}$ or non-volatile, non-watersoluble organics as a particle-phase contaminant. The simulations correspond to Case 1 (the $\mathrm{H}_{2} \mathrm{SO}_{4}$ activity is calculated with use of Eq. (15) and the tabulated $\mathrm{H}_{2} \mathrm{SO}_{4}$ chemical potentials from Giauque et al., 1960; see Supplement, Table S1, simulation 28) and Case $2 \mathrm{a}, K_{\mathrm{H}_{2} \mathrm{SO}_{4}}=2.40 \times 10^{9} \mathrm{~mol} \mathrm{~kg}^{-1}$ and ${ }^{x} K_{\mathrm{SO}_{3}}=1.43 \times 10^{10}$ at $T=288.8 \mathrm{~K}$ (see Supplement, Table S1, simulations 29, 33, 34 and 36). The pure-liquid saturation vapour pressures of $\mathrm{H}_{2} \mathrm{SO}_{4}$ and $\mathrm{SO}_{3}$ are calculated with Eq. (11) (Kulmala and Laaksonen, 1990; Noppel et al., 2002) and Eq. (12) (Nickless, 1968), respectively.

sulfuric acid droplets (Eq. 13) compared to the temperature dependence expected if we only consider the temperature effect of the pure-liquid saturation vapour pressures (Fig. S5).

Figure 5 compares the measured and modelled GMD evolution during experiment 3. For the simulations we use either the same temperature dependence as suggested by Que et al. (2011) $\left(B_{\mathrm{H}_{2} \mathrm{SO}_{4}}=3475 \mathrm{~K}\right.$ and $\left.B_{\mathrm{SO}_{3}}=14245.7 \mathrm{~K}\right)$ or no temperature dependence of $K_{\mathrm{H}_{2} \mathrm{SO}_{4}}$ and ${ }^{x} K_{\mathrm{SO}_{3}}\left(B_{\mathrm{H}_{2} \mathrm{SO}_{4}}=\right.$ $0 \mathrm{~K}$ and $B_{\mathrm{SO}_{3}}=0 \mathrm{~K}$ ) or weak temperature dependence $B_{\mathrm{H}_{2} \mathrm{SO}_{4}}=0 \mathrm{~K}$ and $B_{\mathrm{SO}_{3}}=-3000 \mathrm{~K}$. One of these model simulations corresponds to Case 1 and the rest to Case $2 \mathrm{a}$ (see Supplement, Table S1, simulation 28 and 29, 33, 34 and 36 , respectively).

For the Case 1 simulation (see Supplement, Table S1, simulation 28) we use Eq. (15) and the tabulated $\mathrm{H}_{2} \mathrm{SO}_{4}$ chemical potentials from Giauque et al. (1960) to derive the $\mathrm{H}_{2} \mathrm{SO}_{4}$ activity. The particle-phase contaminant is assumed to be non-volatile and non-water-soluble organics. In this simulation the modelled particles grow somewhat too much before they start to shrink. For the Case 2a simulation, where the temperature dependences of $K_{\mathrm{H}_{2} \mathrm{SO}_{4}}$ and ${ }^{x} K_{\mathrm{SO}_{3}}$ are described by the $B_{\mathrm{H}_{2} \mathrm{SO}_{4}}$ and $B_{\mathrm{SO}_{3}}$ values derived by Que et al. (2011) (see Supplement, Table S1, simulation 29), the model cannot capture the observed GMD evolution. For the Case 2a simulations with $B_{\mathrm{H}_{2} \mathrm{SO}_{4}}=0 \mathrm{~K}$ and $B_{\mathrm{SO}_{3}}=0 \mathrm{~K}$ (see Supplement, Table S1, simulations 33 and 34) the particlephase contaminant is assumed to be $\mathrm{NH}_{3}$ or non-volatile and non-water-soluble organics. These model simulations, which agree with the observed GMD, indicate that the tem- 
perature dependences of $K_{\mathrm{H}_{2} \mathrm{SO}_{4}}$ and ${ }^{x} K_{\mathrm{SO}_{3}}$ need to be very weak or insignificant $\left(B_{\mathrm{H}_{2} \mathrm{SO}_{4}}=0 \mathrm{~K}\right.$ and $\left.B_{\mathrm{SO}_{3}}=0 \mathrm{~K}\right)$. If the particles are contaminated with $\mathrm{NH}_{3}, B_{\mathrm{SO}_{3}}$ or $B_{\mathrm{H}_{2} \mathrm{SO}_{4}}$ even needs to be negative for optimum fitting (e.g. $B_{\mathrm{H}_{2} \mathrm{SO}_{4}}=0 \mathrm{~K}$ and $B_{\mathrm{SO}_{3}}=-3000 \mathrm{~K}$; see Supplement, Table S1, simulations 36). It is also possible to find good agreement between the modelled and measured GMD evolution if one of $B_{\mathrm{H}_{2} \mathrm{SO}_{4}}$ and $B_{\mathrm{SO}_{3}}$ is negative and the other one is positive $\left(B_{\mathrm{H}_{2} \mathrm{SO}_{4}}=3475 \mathrm{~K}\right.$ and $B_{\mathrm{SO}_{3}}=-10000 \mathrm{~K}$; see Supplement, Table S1, simulation 31). The $\mathrm{H}_{2} \mathrm{SO}_{4}$ and $\mathrm{SO}_{3}$ pure-liquid saturation vapour pressures in these simulations are calculated with Eqs. (11) and (12).

If we instead use the pure-liquid saturation vapour pressure parameterisations from the Aspen Plus Databank (which have somewhat weaker temperature dependences than Eqs. 11 and 12), the model results captures the observed GMD evolution if both $B_{\mathrm{H}_{2} \mathrm{SO}_{4}}$ and $B_{\mathrm{SO}_{3}}$ are zero and $\mathrm{H}_{2} \mathrm{SO}_{4}$ is the only evaporating (SVI) species (Case 1; see Supplement, Table S1, simulation 50) or the main evaporating S(VI) species (Case 2a; see Supplement, Table S1, simulation 51; see Supplement, Fig. S12).

For Case $2 \mathrm{~b}$ and 3 simulations in which we assume that $\mathrm{SO}_{3}$ is responsible for most of the $\mathrm{S}(\mathrm{VI})$ evaporation, the model can never capture the observed GMD evolution. This is the case regardless of the pure-liquid saturation vapour pressure method we use $(\mathrm{N}-\mathrm{K}-\mathrm{L}-\mathrm{Nickless}$ or Aspen Plus Databank; see Supplement, Table S1, simulations 42, 48, 52 and 53).

Based on the simulations of experiment 3 we conclude that most of the $\mathrm{S}(\mathrm{VI})$ that evaporated from the particles probably was in the form of $\mathrm{H}_{2} \mathrm{SO}_{4}$ (cases 1 and 2a). The very weak temperature dependences for $K_{\mathrm{H}_{2} \mathrm{SO}_{4}}$ and ${ }^{x} K_{\mathrm{SO}_{3}}$ needed for the model to capture the GMD evolution during experiment 3 is surprising and calls for further investigation. Part of the explanation to this could be that the AIOMFAC activity coefficient model is developed based on experimental data derived at $298.15 \mathrm{~K}$. The uncertainty arising from the two different pure-liquid saturation vapour pressure parameterisations (temperature-dependent) also limits our ability to fully constrain the $K_{\mathrm{H}_{2} \mathrm{SO}_{4}}$ and ${ }^{x} K_{\mathrm{SO}_{3}}$ values. Based on our experiments and model simulations the equilibrium constant $K_{\mathrm{H}_{2} \mathrm{SO}_{4}}$ should be somewhere in the range 2.0$4.0 \times 10^{9} \mathrm{~mol} \mathrm{~kg}^{-1}$ and the ${ }^{x} \mathrm{~K}_{\mathrm{SO}_{3}}$ needs to be larger than $1.4 \times 10^{10}$ at a temperature of $288.8 \pm 5 \mathrm{~K}$. The type of contamination of the sulfate particles $\left(\mathrm{NH}_{3}\right.$, DMA or a nonvolatile non-water-soluble organic compound) does not have a substantial impact on our results and conclusions.

\subsection{Atmospheric implications}

In the following section, we define an effective saturation concentration of $\mathrm{H}_{2} \mathrm{SO}_{4(\mathrm{~g})}\left(C_{\mathrm{H}_{2} \mathrm{SO}_{4}, \mathrm{~S}}^{*}\right)$ as the sum of the saturation concentration of $\mathrm{H}_{2} \mathrm{SO}_{4}\left(C_{\mathrm{H}_{2} \mathrm{SO}_{4}, \mathrm{~S}}\right)$ and $\mathrm{SO}_{3}\left(C_{\mathrm{SO}_{3}, \mathrm{~S}}\right)$, based on the assumption of rapid conversion of $\mathrm{SO}_{3(\mathrm{~g})}$ to
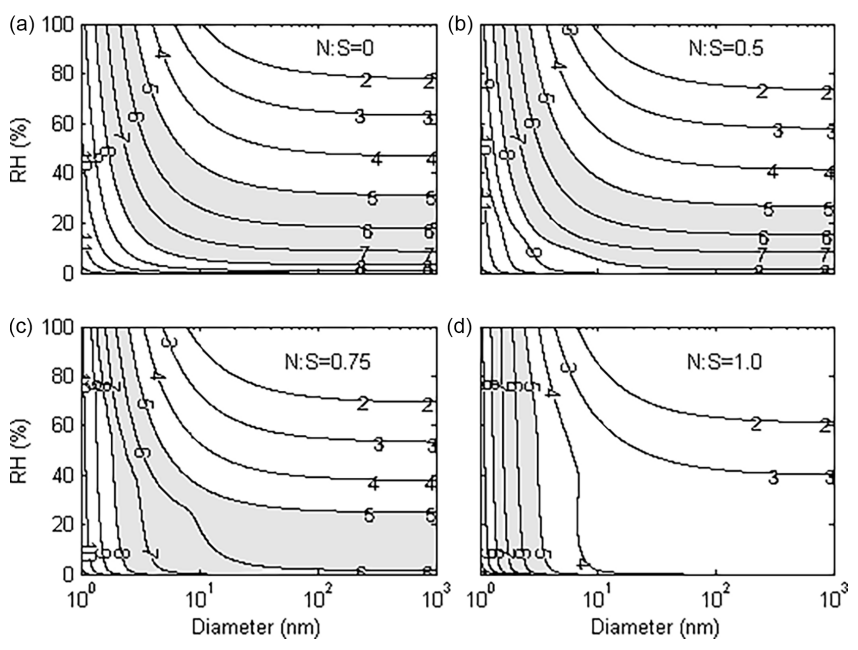

Figure 6. Modelled effective $\mathrm{H}_{2} \mathrm{SO}_{4}$ saturation concentration, $C_{\mathrm{H}_{2} \mathrm{SO}_{4}, \mathrm{~S}}^{*}$ (molecules $\mathrm{cm}^{-3}$ ), expressed in $\log _{10}\left(C_{\mathrm{H}_{2} \mathrm{SO}_{4}, \mathrm{~S}}^{*}\right)$, at $T=288.8 \mathrm{~K}, \mathrm{RH} 0-100 \%$ and particle diameters in the range from 1 to $10^{3} \mathrm{~nm}$. The contours represent $\mathrm{H}_{2} \mathrm{SO}_{4}$ gas-phase concentrations, e.g. $\log _{10}\left(C_{\mathrm{H}_{2} \mathrm{SO}_{4}, \mathrm{~S}}^{*}\right)=7$ corresponds to $C_{\mathrm{H}_{2} \mathrm{SO}_{4}, \mathrm{~S}}^{*}=$ $10^{7}$ molecules $\mathrm{cm}^{-3}$. The grey shading indicates the atmospheric range of $\mathrm{H}_{2} \mathrm{SO}_{4}\left(10^{5-} 10^{8} \mathrm{~cm}^{-3}\right)$. The results correspond to particles composed (a) only of $\mathrm{S}(\mathrm{VI})$ and $\mathrm{H}_{2} \mathrm{O}(\mathrm{N}: \mathrm{S}=0)$, (b) with $\mathrm{N}: \mathrm{S}=0.5$, (c) with $\mathrm{N}: \mathrm{S}=0.75$ and (d) with $\mathrm{N}: \mathrm{S}=1$. The equilibrium constants are $K_{\mathrm{H}_{2} \mathrm{SO}_{4}}=2.40 \times 10^{9} \mathrm{~mol} \mathrm{~kg}^{-1}$ and ${ }^{x} K_{\mathrm{SO}_{3}}=1.43 \times 10^{10}$. The pure-liquid saturation vapour pressures of $\mathrm{H}_{2} \mathrm{SO}_{4}$ and $\mathrm{SO}_{3}$ are calculated with Eqs. (11) and (12).

$\mathrm{H}_{2} \mathrm{SO}_{4(\mathrm{~g})}$, Eq. (22) (see Supplement S5, Fig. S7).

$C_{\mathrm{H}_{2} \mathrm{SO}_{4}, \mathrm{~S}}^{*}=C_{\mathrm{H}_{2} \mathrm{SO}_{4}, \mathrm{~S}}+C_{\mathrm{SO}_{3}, \mathrm{~S}}$

Figure 6 shows the modelled effective $\mathrm{H}_{2} \mathrm{SO}_{4}$ saturation concentration $\left(C_{\mathrm{H}_{2} \mathrm{SO}_{4}, \mathrm{~S}}^{*}\right)$ as a function of particle size $\left(d_{\mathrm{p}}=1-10^{3} \mathrm{~nm}\right)$ and $\mathrm{RH}(0-100 \%)$. The results are from a model simulation with $K_{\mathrm{H}_{2} \mathrm{SO}_{4}}=2.40 \times 10^{9} \mathrm{~mol} \mathrm{~kg}^{-1}$ and ${ }^{x} K_{\mathrm{SO}_{3}}=1.43 \times 10^{10}, T=288.8 \mathrm{~K}$ and pure-liquid saturation vapour pressures calculated with Eqs. (11) and (12). The four different panels (a-d) correspond to simulations using four different values for $\mathrm{N}: \mathrm{S}$, namely $0,0.5,0.75$ and 1. In each panel, the contours show the $\log _{10}\left(C_{\mathrm{H}_{2} \mathrm{SO}_{4}, \mathrm{~S}}^{*}\right)$ levels. For example, the $\log _{10}\left(C_{\mathrm{H}_{2} \mathrm{SO}_{4}, \mathrm{~S}}^{*}\right)=7$ contour corresponds to an effective $\mathrm{H}_{2} \mathrm{SO}_{4}$ saturation concentration of $10^{7}$ molecules $\mathrm{cm}^{-3}$. These contours provide the $\mathrm{H}_{2} \mathrm{SO}_{4}$ gasphase concentration at which the net flux of $\mathrm{S}(\mathrm{VI})$ to and from the particles is zero (particles neither grow nor shrink).

The observed atmospheric daytime range of the $\left[\mathrm{H}_{2} \mathrm{SO}_{4(\mathrm{~g})}\right]$ is approximately $10^{5}-10^{8}$ molecules $\mathrm{cm}^{-3}$, and so we shade this range in Fig. 6. When $C_{\mathrm{H}_{2} \mathrm{SO}_{4}, \mathrm{~S}}^{*}$ is less than this range (to the upper right in the panel), the particles for most atmospheric daytime conditions will grow by condensation of $\mathrm{H}_{2} \mathrm{SO}_{4}$; when $C_{\mathrm{H}_{2} \mathrm{SO}_{4}, \mathrm{~S}}^{*}$ is greater than 
this (to the lower left in the panel) the particles will for most conditions shrink by evaporation of S(VI); in the shaded range the particles will tend to equilibrate. The larger the mole fraction of bases $\left(\mathrm{NH}_{3}\right)$ in the aerosol particles the less prone they will be to shrink. When particles are composed only of $\mathrm{S}(\mathrm{VI})$ and $\mathrm{H}_{2} \mathrm{O}(\mathrm{N}: \mathrm{S}=0)$ and the concentration of $\mathrm{H}_{2} \mathrm{SO}_{4(\mathrm{~g})}$ is $10^{7}$ molecules $\mathrm{cm}^{-3}$ all particles smaller than $10 \mathrm{~nm}$ will shrink at $\mathrm{RH}<13.2 \%$. For the same $\left[\mathrm{H}_{2} \mathrm{SO}_{4(\mathrm{~g})}\right]$ and $\mathrm{N}: \mathrm{S}=0.5$ all particles smaller than $10 \mathrm{~nm}$ shrink at $\mathrm{RH}<12.1 \%$. However, for $\mathrm{N}: \mathrm{S}=0.75$ particles smaller than $4 \mathrm{~nm}$ shrink at $\mathrm{RH}<5.5 \%$, and if $\mathrm{N}: \mathrm{S}=1$ only particles smaller than $\sim 1.9 \mathrm{~nm}$ shrink, independent of RH except when it is extremely dry $(\mathrm{RH} \leq 1.5 \%)$. With the vapour pressure parameterisations from the Aspen Plus Databank and $K_{\mathrm{H}_{2} \mathrm{SO}_{4}}=4.00 \times 10^{9}$ and ${ }^{x} K_{\mathrm{SO}_{3}}=4.55 \times 10^{10}$ the results are almost identical.

These model results demonstrate that sulfuric acid can evaporate from particles or be unable to contribute to their growth for atmospherically relevant conditions, characterised by low relative humility, relatively high temperatures and weak sources of $\mathrm{NH}_{3}$ and $\mathrm{SO}_{2}$. Such environments can be found in the stratosphere and possibly also in the troposphere over large desert regions.

\section{Summary and conclusions}

This study demonstrates, both experimentally and theoretically, the importance of $\mathrm{H}_{2} \mathrm{SO}_{4}$ evaporation from aerosol particles at atmospheric relevant conditions. We measured the sulfate aerosol particle shrinkage below a certain low relative humidity (e.g. $\mathrm{RH}=1.5 \%$ for $T=288.8 \mathrm{~K}$ and $\mathrm{RH}=0.7 \%$ for $T=268.0 \mathrm{~K}$ ) in the CLOUD chamber at CERN. We modelled the sulfur evaporation with ADCHAM. Our model simulation showed the following:

i. The dissociation of $\mathrm{H}_{2} \mathrm{SO}_{4}(\mathrm{aq})$ is not complete, and evaporation of $\mathrm{H}_{2} \mathrm{SO}_{4}$ and $\mathrm{H}_{2} \mathrm{O}$ can explain the observed particle shrinkage. However, we cannot dismiss the possibility that some of the shrinkage is due to evaporating $\mathrm{SO}_{3}$, which is formed when $\mathrm{H}_{2} \mathrm{SO}_{4(\mathrm{aq})}$ is dehydrated.

ii. The equilibrium rate coefficient for the first dissociation stage of $\mathrm{H}_{2} \mathrm{SO}_{4(\mathrm{aq})}\left(K_{\mathrm{H}_{2} \mathrm{SO}_{4}}\right)$ falls somewhere in the range $2.0-4.0 \times 10^{9} \mathrm{~mol} \mathrm{~kg}^{-1}$ at $288.8 \pm 5 \mathrm{~K}$.

iii. The equilibrium coefficient for the dehydration of $\mathrm{H}_{2} \mathrm{SO}_{4}\left({ }^{x} K_{\mathrm{SO}_{3}}\right)$ must at least be larger than $1.4 \times 10^{10}$.

The main factors limiting our estimation of $K_{\mathrm{H}_{2} \mathrm{SO}_{4}}$ are uncertainties in the pure-liquid saturation vapour pressure of $\mathrm{H}_{2} \mathrm{SO}_{4}$ and the relative contribution of $\mathrm{SO}_{3}$ to the observed particle evaporation. Other potential sources of error are the uncertainties in the derived activity coefficients, the mass accommodation coefficient of $\mathrm{H}_{2} \mathrm{SO}_{4}$ and solid salt formation during the particle evaporation phase. The model simulations of an experiment where the temperature was gradually increased from 268 to $293 \mathrm{~K}$ indicate that the temperature dependencies of $K_{\mathrm{H}_{2} \mathrm{SO}_{4}}$ and ${ }^{x} K_{\mathrm{SO}_{3}}$ need to be weak. Future studies should focus on constraining the pure-liquid saturation vapour pressures of $\mathrm{H}_{2} \mathrm{SO}_{4}$ and $\mathrm{SO}_{3}$ and the temperature dependence of $K_{\mathrm{H}_{2} \mathrm{SO}_{4}}$ and ${ }^{x} K_{\mathrm{SO}_{3}}$.

In order to be able to make an accurate prediction of the sulfate particles' influence on global climate, their thermodynamic properties need to be properly described in global climate models. Thus, our constraints on the dissociation, $K_{\mathrm{H}_{2} \mathrm{SO}_{4}}$ and dehydration, ${ }^{x} K_{\mathrm{SO}_{3}}$ of $\mathrm{H}_{2} \mathrm{SO}_{4}$ are important contributions to the global aerosol-climate model community. The outcome of this study implies that atmospheric modelling studies, especially those dedicated to new-particle formation, should not by default assume that sulfate particles are non-volatile. Models that exclude the evaporation process provide faster particle formation rates which has a misleading effect on the impact of aerosols on climate.

Our results are especially meaningful for high-altitude new-particle formation (e.g. in the upper troposphere and stratosphere). It has been previously reported that the particle formation (Brock et al., 1995) and the ion-induced nucleation (Lee et al., 2003; English et al., 2011) are sources of new particles in high altitudes. In the upper troposphere and stratosphere general circulation models coupled with aerosol dynamics models use aerosol evaporation as a source of $\left[\mathrm{H}_{2} \mathrm{SO}_{4}(\mathrm{~g})\right]$ (English et al., 2011). The concentration of $\mathrm{H}_{2} \mathrm{SO}_{4(\mathrm{~g})}$ drastically affects new-particle formation rates. The equilibrium constants for the dissociation and dehydration of $\mathrm{H}_{2} \mathrm{SO}_{4}$ reported in this study are needed to accurately model the sulfate aerosol particle evaporation and concentration of $\mathrm{H}_{2} \mathrm{SO}_{4}(\mathrm{~g})$. They may also be important to evaluate particle formation schemes (homogeneous, ion-induced) for stratospheric conditions. These schemes are generally constrained based on tropospheric conditions (English et al., 2011) but applied for stratosphere simulations. Moreover, vapour-phase $\mathrm{H}_{2} \mathrm{SO}_{4}$ in the atmosphere appears to be ubiquitous, even in the absence of photochemistry (Mauldin et al., 2003; Wang et al., 2013); this may partly be due to evaporation of $\mathrm{H}_{2} \mathrm{SO}_{4}$ from aerosol particles.

In a changing climate it will become even more important to understand the thermodynamic properties of the sulfur aerosol particles involved in the development of polar stratospheric clouds and how sulfate aerosols influence the stratospheric $\mathrm{O}_{3}$ layer. Experiments simulating stratospheric conditions $\left(T \approx 200-265 \mathrm{~K}, p \approx 10^{-1}-10^{-3} \mathrm{~atm}, \mathrm{RH} \geq 1.0 \%\right.$ and $\left[\mathrm{H}_{2} \mathrm{SO}_{4}\right] \leq 10^{8}$ molec. $\mathrm{cm}^{-3}$ ) are of great importance. Our results may also assist in explaining the atmospheric sulfur cycle of Venus. The Venusian clouds that are made up largely of sulfuric acid droplets cover an extended temperature range from $260 \mathrm{~K}$ (upper clouds) to $310 \mathrm{~K}$ (middle clouds) and even higher (lower clouds). The scientific understanding of the upper tropospheric and stratospheric sulfate aerosol is of great importance for the global climate and requires further investigation. 
Data availability. Requests for underlying material should be addressed to the corresponding author, Georgios Tsagkogeorgas (george.tsagkogeorgas@tropos.de).

\section{The Supplement related to this article is available online at https://doi.org/10.5194/acp-17-8923-2017-supplement.}

Author contributions. GT and JD designed and performed the experiments. GT, JD and PR analysed the data. PR developed the model code. PR and GT performed the simulations. GT, JD, LR, JT, JGS, and AK collected the data and contributed to the analysis. GT, PR, JD, and NMD assisted in drafting the manuscript. GT, PR, JD, MB, JC, RCF, MK, NMD and FS contributed to scientific interpretation and editing of the manuscript. All authors contributed to the development of the CLOUD facility and analysis instruments and commented on the manuscript.

Competing interests. The authors declare that they have no conflict of interest.

Acknowledgements. We would like to thank CERN for supporting CLOUD with important technical and financial resources, and for providing a particle beam from the CERN Proton Synchrotron. We also thankPatrick Carrie, Louis-Philippe De Menezes, Jonathan Dumollard, Roberto Guida, Katja Ivanova, Francisco Josa, llia Krasin, Robert Kristic, Abdelmajid Laassiri, Osman Maksumov, Serge Mathot, Benjamin Marichy, Herve Martinati, Antti Onnela, Robert Sitals, Hansueli Walther, Albin Wasem and Mats Wilhelmsson for their important contributions to the experiment. This research has received funding from the EC Seventh Framework Programme (Marie Curie Initial Training Network "CLOUD-ITN" no. 215072 and "CLOUD-TRAIN" no. 316662, ERC-Starting "MOCAPAF" grant no. 57360 and ERC-Advanced "ATMNUCLE" grant no. 227463), the German Federal Ministry of Education and Research (project nos. 01LK0902A and 01LK1222A), the Swiss National Science Foundation (project nos. 200020135307 and 206620 141278), the Academy of Finland (Centre of Excellence project no. 1118615 and other projects: 135054, 133872, 251427, 139656, 139995, 137749, 141217, 141451), the Finnish Funding Agency for Technology and Innovation, the Vaisala Foundation, the Nessling Foundation, the Austrian Science Fund (FWF; project no. J3198-N21), the Portuguese Foundation for Science and Technology (project no. CERN/FP/116387/2010), the Swedish Research Council, Vetenskapsradet (grant 2011-5120), the Presidium of the Russian Academy of Sciences and Russian Foundation for Basic Research (grants 08-02-91006-CERN and 12-02-91522CERN), the US National Science Foundation (grants AGS1136479, AGS1447056, AGC1439551 and CHE1012293), the PEGASOS project funded by the European Commission under the Seventh Framework Programme (FP7-ENV-2010-265148), and the Davidow Foundation. We thank the tofTools team for providing tools for mass spectrometry analysis.

Pontus Roldin would like to thank the Cryosphere-Atmosphere Interactions in a Changing Arctic Climate (CRAICC) Nordic
Top-Level Research Initiative and the Swedish Research Council for Environment, Agricultural Sciences and Spatial Planning FORMAS (project no. 214-2014-1445) for financial support.

Edited by: Yafang Cheng

Reviewed by: two anonymous referees

\section{References}

Ayers, G. P., Gillett, R. W., and Gras, J. L.: On the vapour pressure of sulphuric acid, Geophys. Res. Lett. 7, 433-436, 1980.

Bollas, G. M., Chen, C.-C., and Barton, P. I.: Refined electrolyteNRTL model: activity coefficient expressions for application to multi-electrolyte systems, AIChE J., 54, 1608-1624, 2008.

Brock, C. A., Hamill, P., Wilson, J. C., Jonsson, H. H., and Chan, K. R.: Particle Formation in the Upper Tropical Troposphere: A Source of Nuclei for the Stratospheric Aerosol, Science, 270, 1650-1653, 1995.

Canagaratna, M. R., Jayne, J. T., Jimenez, J. L., Allan, J. D., Alfarra, M. R., Zhang, Q., Onasch, T. B., Drewnick, F., Coe, H., Middlebrook, A., Delia, A., Williams, L. R., Trimborn, A. M., Northway, M. J., DeCarlo, P. F., Kolb, C. E., Davidovits, P., and Worsnop, D. R.: Chemical and microphysical characterization of ambient aerosols with the Aerodyne aerosol mass spectrometer, Mass Spectrom. Rev., 26, 185-222, 2007.

Capaldo, K., Corbett, J. J., Kasibhatla, P., Fischbeck, P., and Pandis, S. N.: Effects of ship emissions on sulphur cycling and radiative climate forcing over the ocean, Nature, 400, 743-746, 1999.

Charlson, R. J., Lovelock, J. E., Andreae, M. O., and Warren, S. G.: Oceanic phytoplankton, atmospheric sulphur, cloud albedo and climate, Nature, 326, 655-661, 1987.

Chen, C. C., Britt, H. I., Boston, J. F., and Evans, L. B.: Local composition model for excess Gibbs energy of electrolyte systems. Part I: Single solvent, single completely dissociated electrolyte systems, AIChE J., 28, 588-596, 1982.

Clarke, A. D., Davis, D., Kapustin, V. N., Eisele, F., Chen, G., Paluch, I., Lenschow, D., Bandy, A. R., Thornton, D., Moore, K., Mauldin, L., Tanner, D., Litchy, M., Carroll, M. A., Collins, J., and Albercook, G.: Particle nucleation in the Tropical boundary layer and its coupling to marine sulfur sources, Science, 282, 89-92, 1998.

Clegg, S. L. and Brimblecombe, P.: Application of a Multicomponent Thermodynamic Model to Activities and Thermal Properties of 0-40 mol kg-1 Aqueous Sulfuric Acid from $<200$ to 328 K, J. Chem. Eng. Data, 40, 43-64, 1995.

Clegg, S. L., Brimblecombe, P., and Wexler, A. S.: Thermodynamic model of the system $\mathrm{H}^{+}-\mathrm{NH}_{4}^{+}-\mathrm{Na}^{+}-\mathrm{SO}_{4}^{2-}-\mathrm{NO}_{3}^{-}-\mathrm{CI}^{-}-\mathrm{H}_{2} \mathrm{O}$ at 298.5 K, J. Phys. Chem. A, 102, 2155-2171, 1998.

Curtius, J., Sierau, B., Arnold, F., Baumann, R., Schulte, P., and Schumann, U.: First direct sulfuric acid detection in the exhaust plume of a jet aircraft in flight, Geophys. Res. Lett., 25, 923-926, 1998.

Deshler, T.: A review of global stratospheric aerosol: Measurements, importance, life cycle, and local stratospheric aerosol, Atmos. Res., 90, 223-232, 2008.

Donahue, T. M., Hoffman, J. H., Hodges, R. R., and Watson, A. J.: Venus was wet: A Measurement of the Ratio of Deuterium to Hydrogen, Science, 216, 630-633, 1982. 
Doyle, G. J.: Self-nucleation in the sulphuric acid-water system, J. Chem. Phys., 35, 795-799, 1961.

Drewnick, F., Schneider, J., Hings, S. S., Hock, N., Noone, K., Targino, A., Weimer, S., Borrmann, S.: Measurement of Ambient, Interstitial, and Residual Aerosol Particles on a Mountaintop Site in Central Sweden using an Aerosol Mass Spectrometer and a CVI, J. Atmos. Chem., 56, 1-20, https://doi.org/10.1007/s10874-006-9036-8, 2006.

Duplissy, J., Merikanto, J., Franchin, A., Tsagkogeorgas, G., Kangasluoma, J., Wimmer, D., Vuollekoski, H., Schobesberger, S., Ehrhart, S., Lehtipalo, K., Flagan, R., Brus, D., Donahue, N., Vehkamaki, H., Almeida, J., Amorim, A., Barmet, P., Bianchi, F., Breitenlechner, M., Dunne, E., Henschel, H., Junninen, H., Kirkby, J., Kurten, A., Kupc, A., Maattanen, A., Makhmutv, V., Napari, I., Nieminen, T., Praplan, A., Riccobono, F., Rondo, L., Steiner, G., Tome, A., Baltensperger, U., Carslaw, K., Dommen, L., Hansel, A., Petaja, T., Sipila, M., Stratmann, F., Vrtala, A., Wagner, P., Worsnop, D., Curtius, J., and Kulmala, M.: Effect of ions on sulfuric acid-water binary particle formation 2: Experimental data and comparison with QC-normalized classical nucleation theory, J. Geophys. Res. Atmos., 121, 1752-1775, https://doi.org/10.1002/2015JD023539, 2016.

English, J. M., Toon, O. B., Mills, M. J., and Yu, F.: Microphysical simulations of new particle formation in the upper troposphere and lower stratosphere, Atmos. Chem. Phys., 11, 9303-9322, https://doi.org/10.5194/acp-11-9303-2011, 2011.

Fahey, D. W., Keim, E. R., Boering, K. A., Brock, C. A., Wilson, J. C., Jonsson, H. H., Anthony, S., Hanisco, T. F., Wennberg, P. O., Miake-Lye, R. C., Salawitch, R. J., Louisnard, N., Woodbridge, E.L., Gao, R.S., Donnelly, S. G., Wamsley, R. C., Del Negro, L. A., Solomon, S., Daube, B.C., Wofsy, S. C., Webster, C. R., May, R. D., Kelly, K. K., Loewenstein, M., Podolske, J. R., and Chan, K. R.: Emission measurements of the Concorde supersonic aircraft in the lower stratosphere, Science, 270, 70-74, 1995.

Fiedler, V., Dal Maso, M., Boy, M., Aufmhoff, H., Hoffmann, J., Schuck, T., Birmili, W., Hanke, M., Uecker, J., Arnold, F., and Kulmala, M.: The contribution of sulphuric acid to atmospheric particle formation and growth: a comparison between boundary layers in Northern and Central Europe, Atmos. Chem. Phys., 5, 1773-1785, https://doi.org/10.5194/acp-5-1773-2005, 2005.

Fuchs, N. A. and Sutugin, A. G.: In Topics in Current Aerosol Research, Pergamon Press, 1971.

Galloway, J. N. and Rodhe, H.: Regional atmospheric budgets of S and N fluxes: how well can they be quantified?, Proc. Roy. Soc. Edinburgh 97B, 61-80, 1991.

Giauque, W. F., Hornung, E. W., Kunzler, J. E., and Rubin, T. R.: The thermodynamic properties of aqueous sulphuric acid solutions from 15 to 300K, J. Am. Chem. Soc., 82, 62-70, 1960.

Gmitro, J. T. and Vermeulen, T.: Vapor-liquid equilibria for aqueous sulfuric acid, AIChE J., 10, 740-746, 1964.

Grädel, T. E. and Crutzen, P. J.: Chemie der Atmosphäre, Bedeutung für Klima und Umwelt, Spektrum, Heidelberg, 1994.

Hämeri, K., Väkevä, M., Hanson, H.-C., and Laaksonen, A.: Hygroscopic growth of ultrafine ammonium sulphate aerosol measured using an ultrafine tandem differential mobility analyzer, J. Geophys. Res., 105, 22231-22242, 2000.

Hanson, D. R. and Eisele, F.: Diffusion of $\mathrm{H}_{2} \mathrm{SO}_{4}$ in humidified nitrogen: Hydrated $\mathrm{H}_{2} \mathrm{SO}_{4}$, J. Phys. Chem., A, 104, 1715-1719, 2000 .
Hashimoto, G. L. and Abe, Y.: Stabilization of Venus' climate by a chemical-albedo feedback, Earth Planet. Space, 52, 197-202, 2000.

Hoffman, J. H., Hodges, R. R., Donahue, T. M., and McElroy, M. B.: Composition of the Venus lower atmosphere from the Pioneer Venus mass spectrometer, J. Geophys. Res., 85, 7882-7890, 1980.

Hommel, R., Timmreck, C., and Graf, H. F.: The global middleatmosphere aerosol model MAECHAM5-SAM2: comparison with satellite and in-situ observations, Geosci. Model Dev., 4, 809-834, https://doi.org/10.5194/gmd-4-809-2011, 2011.

Hübert, B. J.: Sulphur emissions from ships, Nature, 400, 713-714, 1999.

Hyvärinen, A.-P., Raatikainen, T., Laaksonen, A., Viisanen, Y., and Lihavainen, $\mathrm{H}$.: Surface tensions and densities of $\mathrm{H}_{2} \mathrm{SO}_{4}+$ $\mathrm{NH}_{3}+$ water solutions, Geophys. Res. Lett., 32, L16806, https://doi.org/10.1029/2005GL023268, 2005.

Jacobson, M. Z.: Fundamentals of Atmospheric Modelling, 2nd Edn., Cambridge University Press, Cambridge, United Kingdom and New York, NY, USA, ISBN: 052154865 9, 2005.

Jayne, J. T., Pöschl, U., Chen, Y., Dai, D., Molina, L. T., Worsnop, D. R., Kolb, C. E., and Molina, M. J.: Pressure and Temperature Dependence of the Gas-Phase Reaction of $\mathrm{SO}_{3}$ with $\mathrm{H}_{2} \mathrm{O}$ and the Heterogeneous Reaction of $\mathrm{SO}_{3}$ with $\mathrm{H}+2 \mathrm{O} / \mathrm{H}_{2} \mathrm{SO}_{4}$ Surfaces, J. Phys. Chem. A, 101, 10000-10011, 1997.

Jimemez, J. L., Jayne, J. T., Shi, Q., Kolb, C. E., Worsnop, D. R., Yourshaw, I., Seinfeld, J. H., Flagan, R. C., Zhang, X., Smith, K. A., Morris, J., and Davidovits, P.: Ambient aerosol sampling with an aerosol mass spectrometer. J. Geophys. Res.-Atmos., 108, 8425, https://doi.org/10.1029/2001JD001213, 2003.

Kiang, C. S. and Stauffer, D.: Chemical nucleation theory for various humidities and pollutants, Faraday Symp. Chem. Soc., 7, 26-33, 1973.

Kiene, R. P.: Sulphur in the mix, Nature, 402, 363-365, 1999.

King, H. H., Hall, J. L., and Ware, G. C.: A study of the density, surface tension and adsorption in the water-ammonia system at $20^{\circ}$, J. Am. Chem. Soc., 52, 5128-5135, 1930.

Kirkby, J., Curtius, J., Almeida, J., Dunne, E., Duplissy, J., Ehrhart, S., Franchin, A., Gagné, S., Ickes, L., Kürten, A., Kupc, A., Metzger, A., Riccobono, F., Rondo, L., Schobesberger, S., Tsagkogeorgas, G., Wimmer, D., Amorim, A., Bianchi, F., Breitenlechner, M., David, A., Dommen, J., Downard, A., Ehn, M., Flagan, R., Haider, S., Hansel, A., Hauser, D., Jud, W., Junninen, H., Kreissl, F., Kvashin, A., Laaksonen, A., Lehtipalo, K., Lima, J., Lovejoy, E., Makhmutov, V., Mathot, S., Mikkilä, J., Minginette, P., Mogo, S., Nieminen, T., Onnela, A., Pereira, P., Petäjä, T., Schnitzhofer, R., Seinfeld, J., Sipilä, M., Stozhkov, Y., Stratmann, F., Tomé, A., Vanhanen, J., Viisanen, Y., Aron Vrtala, A., Wagner, P., Walther, H., Weingartner, E., Wex, H., Winkler, P., Carslaw, K., Worsnop, D.,Baltensperger, U., and Kulmala, M.: Role of sulphuric acid, ammonia and galactic cosmic rays in atmospheric aerosol nucleation, Nature, 476, 429-433, 2011.

Kokkola, H., Hommel, R., Kazil, J., Niemeier, U., Partanen, A.-I., Feichter, J., and Timmreck, C.: Aerosol microphysics modules in the framework of the ECHAM5 climate model - intercomparison under stratospheric conditions, Geosci. Model Dev., 2, 97-112, https://doi.org/10.5194/gmd-2-97-2009, 2009. 
Korhonen, P., Laaksonen, A., Batris, E., and Viisanen, Y.: Thermodynamics for highly concentrated water-ammonium sulfate solutions, J. Aerosol Sci., 29, 379-380, 1998.

Kuang, C., McMurry, P. H., McCormick, A. V., and Eisele, F. L.: Dependence of nucleation rates on sulfuric acid vapor concentration in diverse atmospheric locations, J. Geophys. Res., 113, D10209, https://doi.org/10.1029/2007JD009253, 2008.

Kulmala, M. and Laaksonen, A.: Binary nucleation of watersulfuric acid system: Comparison of classical theories with different $\mathrm{H}_{2} \mathrm{SO}_{4}$ saturation vapor pressures, J. Chem. Phys., 93, 696-701, 1990.

Kulmala, M., Pirjola, L., and Mäkelä, J. M.: Stable sulphate clusters as a source of new atmospheric particles, Nature 404, 66-69, 2000.

Kürten, A., Rondo, L., Ehrhart, S., and Curtius, J.: Performance of a corona ion source for measurement of sulfuric acid by chemical ionization mass spectrometry, Atmos. Meas. Tech., 4, 437-443, https://doi.org/10.5194/amt-4-437-2011, 2011.

Kürten, A., Rondo, L., Ehrhart, S., and Curtius, J.: Calibration of a Chemical Ionization Mass Spectrometer for the Measurement of Gaseous Sulfuric Acid, J. Phys. Chem. A, 116, 6375-6386, https://doi.org/10.1021/jp212123n, 2012.

Laaksonen, A. and Kulmala, M.: Homogeneous heteromolecular nucleation of sulphuric acid and water vapours in stratospheric conditions: A theoretical study of the effect of hydrate interaction, J. Aerosol Sci., 22, 779-787, 1991.

Lai, A. and Nazaroff, W. W.: Modelling indoor particle deposition from turbulent flow onto smooth surfaces, J. Aerosol Sci., 31, 463-476, 2000.

Lee, S.-H., Reeves, J. M., Wilson, J. C., Hunton, D. E., Viggiano, A. A., Miller, T. M., Ballenthin, J. O., and Lait L. R.: Particle formation by ion nucleation in the upper troposphere and lower stratosphere, Science, 301, 1886-1889, 2003.

Lehtinen, K. E. J. and Kulmala, M.: A model for particle formation and growth in the atmosphere with molecular resolution in size, Atmos. Chem. Phys., 3, 251-257, https://doi.org/10.5194/acp-3251-2003, 2003.

Margarella, A. M., Perrine, K. A., Lewis, T., Faubel, M., Winter, B., and Hemminger, J. C.: Dissociation of sulfuric acid in aqueous solution: Determination of the photoelectron spectral fingerprints of $\mathrm{H}_{2} \mathrm{SO}_{4}, \mathrm{HSO}_{4}^{-}$, and $\mathrm{SO}_{4}^{2-}$ in water, J. Phys. Chem. C, 117, 8131-8137, 2013.

Marti, J. J., Jefferson, A., Ping Cai, X., Richert, C, McMurry, P. H., and Eisele, F.: $\mathrm{H}_{2} \mathrm{SO}_{4}$ vapor pressure of sulfuric acid and ammonium sulfate solutions, J. Geophys. Res., 102, 3725-3735, 1997.

Mauldin, R. L., III, Cantrell, C. A., Zondlo, M., Kosciuch, E., Eisele, F. L., Chen, G., Davis, D., Weber, R., Crawford, J., Blake, D., Bandy, A., and Thornton, D.: Highlights of $\mathrm{OH}, \mathrm{H}_{2} \mathrm{SO}_{4}$, and methane sulfonic acid measurements made aboard the NASA P-3B during Transport and Chemical Evolution over the Pacific, J. Geophys. Res., 108, 8796, https://doi.org/10.1029/2003JD003410, 2003.

Mills, F. P., Esposito, L. W., and Yung, Y. L.: Atmospheric composition, chemistry, and clouds, in: Exploring Venus as a Terrestrial Planet, edited by: Esposito, L. W., Stofan, E. R., and Cravens, T. E., American Geophysical Union, Washington, DC, 73-100, 2007.
Moroz, V. I., Parfentev, N. A., and Sanko, N. F.: Spectrophotometric experiment on the Venera 11 and 12 descent modules. 2. Analysis of Venera 11 spectra by layer-addition method, Cosmis. Res., 17, 601-614, 1979.

Nickless, G. (Ed.): “Inorganic Sulfur Chemistry”, Elsevier, Amsterdam, 1968.

Noppel, M., Vehkamäki, H., and Kulmala, M.: An improved model for hydrate formation in sulfuric-acid water nucleation, J. Chem. Phys., 116, 218-228, 2002.

Öm, G., Hansson, U., and Rodhe, H.: Historical worldwide emissions of anthropogenic sulfur: 1860-1985, Department of Meteorology, Stockholm University, Report CM-91, 1996.

Petters, M. D. and Kreidenweis, S. M.: A single parameter representation of hygroscopic growth and cloud condensation nucleus activity, Atmos. Chem. Phys., 7, 1961-1971, 2007.

Pöschl, U., Canagaratna, M., Jayne, J. T., Molina, L. T., Worsnop, D. R., Kolb, C. E., and Molina, M. J.: Mass accommodation coefficient of $\mathrm{H}_{2} \mathrm{SO}_{4}$ vapor on aqueous sulfuric acid surfaces and gaseous diffusion coefficient of $\mathrm{H}_{2} \mathrm{SO}_{4}$ in $\mathrm{N}_{2} / \mathrm{H}_{2} \mathrm{O}$, J. Phys. Chem. A, 102, 10082-10089, 1998.

Prinn, R. G.: Venus: Composition and Structure of the Visible Clouds, Science, 182, 1132-1135, 1973.

Que, H., Song, Y., and Chen, C.: Thermodynamic modeling of the sulfuric acid-water-sulfur trioxide system with the symmetric Electrolyte NRTL model, J. Chem. Eng. Data, 56, 963-977, 2011.

Rohde, H.: Human impact on the atmospheric sulfur balance, Tellus, 51A-B, 110-122, 1999.

Roedel, W.: Measurements of sulfuric acid saturation vapor pressure: Implications for aerosol formation by heteromolecular nucleation, J. Aerosol Sci., 10, 375-386, 1979.

Roldin, P., Eriksson, A. C., Nordin, E. Z., Hermansson, E., Mogensen, D., Rusanen, A., Boy, M., Swietlicki, E., Svenningsson, B., Zelenyuk, A., and Pagels, J.: Modelling non-equilibrium secondary organic aerosol formation and evaporation with the aerosol dynamics, gas- and particle-phase chemistry kinetic multilayer model ADCHAM, Atmos. Chem. Phys., 14, 7953-7993, https://doi.org/10.5194/acp-14-7953-2014, 2014.

Roldin, P., Liao, L., Mogensen, D., Dal Maso, M., Rusanen, A., Kerminen, V.-M., Mentel, T. F., Wildt, J., Kleist, E., KiendlerScharr, A., Tillmann, R., Ehn, M., Kulmala, M., and Boy, M.: Modelling the contribution of biogenic volatile organic compounds to new particle formation in the Jülich plant atmosphere chamber, Atmos. Chem. Phys., 15, 10777-10798, https://doi.org/10.5194/acp-15-10777-2015, 2015.

Simó, R. and Pedrós-Alió, C.: Role of vertical mixing in controlling the oceanic production of dimethyl sulphide, Nature, 402, 396399, 1999.

Simpson, D., Fagerli, H., Hellsten, S., Knulst, J. C., and Westling, O.: Comparison of modelled and monitored deposition fluxes of sulphur and nitrogen to ICP-forest sites in Europe, Biogeosciences, 3, 337-355, https://doi.org/10.5194/bg-3-3372006, 2006.

Smith, S. J., Pitcher, H., and Wigley, T. M. L: Global and Regional Anthropogenic Sulfur Dioxide Emissions, Global Planet. Change, 29, 99-119, 2001.

Song, Y. and Chen, C.-C.: Symmetric Electrolyte Nonrandom Two-Liquid Activity Coefficient Model, Ind. Eng. Chem. Res., 48, 7788-7797, 2009. 
Stauffer, D.: Kinetic theory of two-component ("heteromolecular") nucleation and condensation, J. Aerosol Sci., 7, 319-333, 1976.

Sullivan, R. C., Petters, M. D., DeMott, P. J., Kreidenweis, S. M., Wex, H., Niedermeier, D., Hartmann, S., Clauss, T., Stratmann, F., Reitz, P., Schneider, J., and Sierau, B.: Irreversible loss of ice nucleation active sites in mineral dust particles caused by sulphuric acid condensation, Atmos. Chem. Phys., 10, 1147111487, https://doi.org/10.5194/acp-10-11471-2010, 2010.

Turco, R. P., Whitten, R. C., and Toon, O. B.: Stratospheric aerosols: Observation and theory, Rev. Geophys. Space Phys., 20, 233 279, 1982

Vaida, V., Kjaergaard, H. G., Hintze, P. E., and Donaldson, D. J.: Photolysis of sulfuric acid vapor by visible solar radiation, Science, 299, 1566-1568, 2003.

Vehkamäki, H., Kulmala, M., Napari, I., Lehtinen, K. E. J., Timmreck, C., Noppel, M., and Laaksonen, A.: An improved parameterization for sulfuric acid-water nucleation rates for tropospheric and stratospheric conditions, J. Geophys. Res., 107, 4622, https://doi.org/10.1029/2002JD002184, 2002.

Volmer, M. and Weber, A.: Keimbildung in übersättigten Gebilden, Z. Phys. Chem., 119, 277-301, 1926.

Walrafen, G. E., Yang, W. H., Chu, Y. C., and Hokmabadi, M. S.: Structures of Concentrated Sulfuric Acid Determined from Density, Conductivity, Viscosity, and Raman Spectroscopic Data, J. Solution Chem., 29, 905-936, 2000.

Wang, P., Anderko, A., Springer, R. D., and Young, R. D.: Modeling Phase Equilibria and Speciation in Mixed-Solvent Electrolyte Systems: II. Liquid-Liquid Equilibria and Properties of Associating Electrolyte Solutions, J. Mol. Liq., 125, 37-44, 2006.

Wang, S. C. and Flagan, R. C.: Scanning electrical mobility spectrometer, Aerosol Sci. Technol., 13.2, 230-240, 1990.

Wang, Z. B., Hu, M., Mogensen, D., Yue, D. L., Zheng, J., Zhang, R. Y., Liu, Y., Yuan, B., Li, X., Shao, M., Zhou, L., Wu, Z. J., Wiedensohler, A., and Boy, M.: The simulations of sulfuric acid concentration and new particle formation in an urban atmosphere in China, Atmos. Chem. Phys., 13, 11157-11167, https://doi.org/10.5194/acp-13-11157-2013, 2013.
Weber, R. J., McMurry, P. H., Mauldin, R. L., Tanner, D. J., Eisele, F. L., Clarke, A. D., and Kapustin, V. N.: New Particle Formation in the Remote Troposphere: A Comparison of Observations at Various Sites, Geophys. Res. Lett., 26, 307-310, 1999.

Wen, H. and Carignan, J.: Reviews on atmospheric selenium: Emissions, speciation and fate, Atmos. Environ., 41, 7151-7165, 2007.

Wilson, J. C., Jonsson, H. H., Brock, C. A., Toohey, D. W., Avallone, L. M., Baumgardner, D., Dye, J. E., Poole, L. R., Woods, D. C., DeCoursey, R. J., Osborn, M., Pitts, M. C., Kelly, K. K., Chan, K. R., Ferry, G. V., Loewenstein, M., Podolske, J. R., and Weaver, A.: In situ observations of aerosol and chlorine monoxide after the 1991 eruption of Mount Pinatubo: effect of reactions on sulfate aerosol, Science, 261, 1140-1143, 1993.

Yu, F. and Turco, R. P.: From molecular clusters to nanoparticles: Role of ambient ionization in tropospheric aerosol formation, J. Geophys. Res.-Atmos., 106, 4797-4814, 2001.

Zhang, X., Liang, M. C., Montmessin, F., Bertaux, J. L., Parkinson, C., and Yung, Y. L.: Photolysis of sulphuric acid as the source of sulphur oxides in the mesosphere of Venus, Nature, 3, 834-837, 2010.

Zuend, A., Marcolli, C., Luo, B. P., and Peter, T.: A thermodynamic model of mixed organic-inorganic aerosols to predict activity coefficients, Atmos. Chem. Phys., 8, 4559-4593, https://doi.org/10.5194/acp-8-4559-2008, 2008.

Zuend, A., Marcolli, C., Booth, A. M., Lienhard, D. M., Soonsin, V., Krieger, U. K., Topping, D. O., McFiggans, G., Peter, T., and Seinfeld, J. H.: New and extended parameterization of the thermodynamic model AIOMFAC: calculation of activity coefficients for organic-inorganic mixtures containing carboxyl, hydroxyl, carbonyl, ether, ester, alkenyl, alkyl, and aromatic functional groups, Atmos. Chem. Phys., 11, 9155-9206, https://doi.org/10.5194/acp-11-9155-2011, 2011. 